\title{
COVID-19: The impact of social distancing policies, cross-country analysis
}

\author{
Gonzalo Castex $^{1} \cdot$ Evgenia Dechter $^{1}$ (D) $\cdot$ Miguel Lorca $^{1}$
}

Received: 14 July 2020 / Accepted: 29 August 2020 / Published online: 15 October 2020

(C) Springer Nature Switzerland AG 2020

\begin{abstract}
At the onset of the COVID-19 pandemic a large number of countries introduced a range of non-pharmaceutical interventions. Whereas the policies are similar across countries, country characteristics vary substantially. We examine the effectiveness of such policies using a cross-country variation in socio-economic, environmental and geographic, and health system dimensions. The effectiveness of policies that prescribe closures of schools and workplaces is declining with population density, country surface area, employment rate and proportion of elderly in the population; and increasing with GDP per capita and health expenditure. Cross-country human mobility data reinforce some of these results. We argue that the findings can be explained by behavioural response to risk perceptions and resource constraints. Voluntary practice of social distancing might be less prevalent in communities with lower perceived risk, associated with better access to health care and smaller proportion of elderly population. Higher population density, larger geographical area, and higher employment rate may require more resources to ensure compliance with lockdown policies.
\end{abstract}

Keywords COVID-19 · Non-pharmaceutical interventions · Cross-country analysis

\section{Introduction}

The outbreak of COVID-19 has caused major public health concerns around the world. Since the first cases in late 2019 in China, COVID-19 has spread exponentially around the world, indicating an endemic person-to-person transmission.

This article is part of the Topical Collection on Economics of COVID-19.

Gonzalo Castex

g.castexhernandez@unsw.edu.au

Evgenia Dechter

e.dechter@unsw.edu.au

Miguel Lorca

m.lorca@unsw.edu.au

1 School of Economics, University of New South Wales, New South Wales, Australia 
In an attempt to flatten the transmission of the virus, governments in many countries implemented a range of non-pharmaceutical interventions (NPIs), including closures of schools, workplaces, public transport, cancellations of public events, restrictions of internal movement, tracing infected persons contacts, enhanced testing, and more. Timelines of these policies vary across countries, but by mid-April 2020, due to the virus crisis around $70 \%$ of countries have enacted one or more of these measures. ${ }^{1}$ The effectiveness of each NPI may vary with a range of other actions taken by the government and communities at the time of the crisis. To assess these differences, we examine how the effectiveness of NPIs varies with country characteristics.

Using a dynamic version of the Susceptible-Infected-Recovered (SIR) model, we examine how the impact of NPIs on transmission rate of COVID-19 varies with a range of country characteristics along economic, public health and environment dimensions. These characteristics are associated with differences in behavioral response and differences in resources available to governments that might be required to enforce these policies. Our findings suggests that these factors play important roles in slowing down the spread of the virus during NPIs; the results also suggest that the economic and social systems as well as incentives and attitudes may lead to different outcomes of NPIs.

At the environmental dimension, we account for population density, pollution, and surface area factors. Higher population density may increase the frequency of human interactions and affect the compliance with the social distancing rules; therefore, the spread of the virus might be higher in such communities and lockdown policies less effective. It has also been previously established that an epidemic of a respiratory disease, such as influenza, initially affects the more densely populated urban areas (see for example, Zachreson et al. (2018), using Australian data). Higher concentrations of air pollutants are associated with higher likelihood of chronic respiratory conditions and therefore present an additional risk factor. For example, Conticini et al. (2020), using Italian data, conclude that pollution is an additional factor of increased lethality from COVID-19; Wu and McGoogan (2020b) reach similar conclusions using US data. Additionally, Setti et al. (2020) show that the airborne transmission of COVID-19 might be more prevalent in areas with higher air pollution.

At the socio-economic dimension, we account for GDP per capita and employment rate. Higher employment rates may increase the risk of exposure to viruses and therefore increase the spread. For example, Markowitz et al. (2019), using the US data, show that increases in employment are associated with increased incidence of influenza; Adda (2016) uses French data and shows that viruses spread faster during economic booms. Access to leave and sick benefits may increase the incentives to work for those who display symptoms of sickness and increase the spread of the virus, see for example, Barmby and Larguem (2009) (using UK data) and Pichler and Ziebarth (2017) (using US and German data). Better economic conditions at the onset of the pandemic may also provide better access to funds for governments, providing resources for better benefits and enforcement practices.

At the health system dimension, we account for health expenditure as \% GDP, proportion of physicians in population, and proportion of elderly population. Research shows that elderly face higher COVID-19 associated risks. ${ }^{2}$ A response to the higher risk might be in form of higher prevalence in voluntary social distancing. On the other hand, for the general

\footnotetext{
${ }^{1}$ Authors calculations, using the Oxford COVID-19 Government Response Tracker dataset.

${ }^{2}$ Medical research shows that deaths from COVID-19-related illness are heavily concentrated among the elderly and those with underlying health conditions. See for example, Wu and McGoogan (2020b) and Verity et al. (2020), CDC COVID-19 Response Centers for Disease Control and Prevention COVID-19 Response Team (2020).
} 
population, taking into account the proportion of elderly, access to a more advanced health system might be correlated with a lower perceived risk of becoming severely ill; therefore, lower incentives to exercise voluntary social distancing before NPIs are enacted.

The dataset is constructed using four data sources. The Oxford COVID-19 Government Response Tracker provides measures of government responses to COVID-19 spread. For more details about the dataset, see Hale et al. (2020). We obtain data on the number of recorded COVID-19 cases from the Center for Systems Science and Engineering at Johns Hopkins University. Google Mobility Reports provide daily country level information on human mobility across a range of location categories. Country-level characteristics are from the World Bank data.

We show that NPIs which impose strict social distancing rules, such as school and workplace closures, are more effective in countries with lower population density, lower surface area, lower air pollution, higher GDP per capita, lower employment rate, higher health expenditure, and lower proportion of elderly population. We attribute the differences in effectiveness of NPIs to incentives driven behaviors and public resource constraints. Compliance with closures and lockdowns may demand more resources in places with higher population density, larger geographical area, and higher employment rate, impairing the effectiveness of these policies. Communities with access to a better health care, measured by health expenditure as \% of GDP, may have less incentives to voluntary reduce social interactions; therefore, social distancing measures in such communities could be more effective. A cross-country analysis of Google mobility data reinforces these results and interpretations. Individuals in countries with higher proportion of physicians per 1000 persons and higher health expenditure as \% of GDP are less likely to increase their time spent at home prior to schools and workplace closures. ${ }^{3}$ On the other hand, after the implementation of workplaces and/or school closures, the proportional increase in time spent at home is higher in countries with better access to health system and lower in countries with higher proportion of elderly.

Extensive testing is more effective in countries with higher GDP per capita, larger surface area, higher air pollution, lower health expenditure, and higher proportion of elderly in population. Variation in testing intensity and its potential correlation with the GDP per capita could explain some of these results. Recent studies point out the existence of complementarities between social distancing behaviors and testing: enhanced testing policy can lead to more social activity and less social distancing, (see for example, Acemoglu et al. 2020). Such complementarities appear to be more likely in countries with better health systems, proxied by health expenditure as a proportion of GDP, and lower proportions of elderly population.

There are now a number of studies evaluating the effectiveness of NPIs. Askitas et al. (2020) show that some NPIs are more effective than others; Chen and Qiu (2020) detail these differences in terms of costs and benefits. Jinjarak et al. (2020) document that more stringent policies are associated with lower mortality growth rates and report cross-country differences. Kucharski et al. (2020) estimate that in China, the basic reproduction rate declines from 2.35 one week before travel restrictions to 1.05 one week after travel restrictions. Friedson et al. (2020), using daily COVID-19 data in California, find that the lockdown reduced the number of cases by 125.5 to 219.7 (per 100,000 population) and led to 1,661 fewer deaths during the first month following its implementation. Fang et al. (2020) study

\footnotetext{
${ }^{3}$ Using mobility measures between 10 to 6 days before work or school closures, compared to mobility measures before the onset of the first wave of COVID-19 pandemic.
} 
the impact of lockdown in Wuhan, China enacted on January 23, 2020; they show that the COVID-19 cases would be $64.8 \%$ higher in the 347 Chinese cities outside Hubei province, and $52.64 \%$ higher in the 16 non-Wuhan cities inside Hubei, in the counterfactual world in which the city of Wuhan were not locked down. Cho (2020) shows that lockdown policies are effective in lowering excess mortality. Ullah and Ajala (2020) find that lockdown significantly affects the number of confirmed cases after 7 days of its implementation; Hartl et al. (2020) show a trend break in the transmission rate on the 9th day in Germany.

A number of studies examine the socio-economic inequalities associated with the COVID crisis along several dimensions. Ahmed et al. (2020) show that addressing inequality could be important in mitigating the spread of the virus. Borjas (2020) shows that more disadvantaged populations are less likely to be tested but more likely to be infected conditional on testing. Brzezinski et al. (2020) show that the more disadvantaged communities tend to have lower uptake of voluntary physical distancing in response to the outbreak of the crisis. Earlier epidemiology literature shows that there is considerable variation in individual infectiousness, model predictions that control for individual variation differ sharply from average-based approaches, with disease extinction more likely and outbreaks more rare but more explosive; suggesting that targeted control policies are more effective than general policies (see for example, Lloyd-Smith et al. 2005). Our results complement this literature showing that there is a substantial heterogeneity in the effectiveness of government response policies. This heterogeneity can be attributed to endogenous social distancing behavior; and differences in resources devoted to the policy.

\section{Data}

The dataset combines daily government response data, daily reported COVID-19 cases data, and country-level aggregate characteristics.

Cross-country government response policies data are from the Oxford COVID-19 Government Response Tracker (OxCGRT). ${ }^{4}$ Hale et al. (2020) provide an extensive description of the data and its collection. There are 201 countries and territories, 178 of which have reported at least one case of COVID-19 by April 15 2020, 139 have implemented at least one NPI. Appendix Table 6 summarizes the policies and average dates.

The OxCGRT also reports the COVID-19 Government Response Stringency Index, calculated using selected NPIs excluding contact tracing and extended testing). The value of the index on any given day is the average of the indicators for each policy. Each NPI receives a score between 0 and 3 (or 0 and 2), where zero implies no policy or missing information, 1 implies targeted policy and 2 or 3 implies more general policy. The index is rescaled to create a score between 0 and 100 .

The number of COVID-19 cases for 22 January - 11 May 2020 is provided by Center for Systems Science and Engineering (CSSE) at Johns Hopkins University. ${ }^{5}$ Since the accounting of positive cases may vary substantially across countries due to different testing and reporting practices, most estimations control for country fixed effects.

A significant amount of effort has been put into creating the OxCGRT and CSSE datasets. However, there are differences in how COVID-19 cases are tested and reported across

\footnotetext{
${ }^{4}$ The data are available at https://covidtracker.bsg.ox.ac.uk.

${ }^{5}$ The data are available at: https://github.com/CSSEGISandData/COVID-19/tree/master/csse_covid_19_data/ csse_covid_19_time_series.
} 
countries. For a number of countries response policies such as schools and workplace closures are reported as initiated on the same day as the first reported case. We assume that these reportings are due to measurement errors and include only those countries which had at least 20 reported cases on the day of the school closures policy implementation. This restriction leaves us with 55 countries.

The third data source are daily Google Mobility Reports released by Google in May $2020 .^{6}$ These aggregated data are from mobile device location history reported for six location categories: retail and recreation, grocery and pharmacy, parks, public transit, workplaces and residential areas. The reports show how visits to these locations and length of stay in a given location change over time. A baseline day represents a normal value for that day of the week. The baseline day is the median value for the 5 week period between Jan 3 to Feb 6, 2020.

The fourth data source is the World Bank Databank, which provides a range of aggregate measures on health, geography and the state of economy. ${ }^{7}$ We use the most recent available measures. The measures include health expenditure \%GDP (2017), number of physicians per 1000 population (2008-2017), proportion of population above 65 years old (2017), GDP per capita (2017, in constant \$US), employment rate (2017), surface area in $\mathrm{km}^{2}$ (20132017), population density (2017), and air pollution (PM2.5) (2017). Appendix Table 7 provides summary statistics for the selected 55 countries. All estimations use normalized standardized measures of country specific characteristics.

\section{Estimation}

To assess the effectiveness of NPIs we use the Susceptible-Infected-Recovered (SIR) model with time-varying parameters. We utilize the dynamic version of the SIR model, as in Chen and Qiu (2020), who augment this model to test for the effectiveness of various NPIs across nine countries. We apply their methodology in our analysis.

The time-varying SIR model is described by a system of differential equations,

$$
\begin{aligned}
\frac{\partial S_{j}}{\partial t} & =-\frac{\beta_{j}(t) S_{j}(t)}{N_{j}} I_{j}(t) \\
\frac{\partial I_{j}}{\partial t} & =\frac{\beta_{j}(t) S_{j}(t)}{N_{j}} I(t)-\gamma_{j}(t) I_{j}(t) \\
\frac{\partial R_{j}}{\partial t} & =\gamma_{j}(t) I_{j}(t)
\end{aligned}
$$

The model assumes that the population, $N_{j}$, in country $j$ is divided into three groups: susceptible, $S_{j}(t)$; infected, $I_{j}(t)$, and recovered, $R_{j}(t)$. Population size is assumed to be constant since we focus on a relatively short time period. The country-specific time varying parameter $\beta_{j}(t)$ represents the transmission rate of the virus in country $j$, the value $\beta$ reflects the rate at which contacts occur in the population and the probability of transmission occurring when a susceptible and infected meet. Each of the $I_{j}(t)$ infected individuals can transmit the disease with probability $\beta_{j}(t) \frac{S_{j}(t)}{N_{j}}$. Infected individuals recover at rate $\gamma_{j}(t)$.

\footnotetext{
${ }^{6}$ The data are available at https://www.google.com/covid19/mobility/; last accessed 18 May 2020

${ }^{7}$ The data are available at https://data.worldbank.org
} 
Without behavioral changes or interventions $\beta_{j}(t)$ does not vary over time; however, $\beta_{j}(t)$ may change with NPIs or due to changing behavior.

In the classical SIR model, assuming that for a large $N$ early in the outbreak, $S(t) / N \approx$ 1 , the reproduction rate, $R_{0 j}=\beta_{j}(t) / \gamma_{j}(t)$, which determines the number of additional infections by an infected person before he/she recovers. If $R_{0 j}>1$, the disease will spread exponentially and will infect a large fraction of the total population. In the dynamic SIR model, $R_{0 j}$ can change with $\beta_{j}(t)$. Assuming constant $\gamma$, we estimate the change in $\beta_{j}(t)$ as a function of country-specific characteristics to examine the effectiveness of NPIs.

The change in the number of infected in country $j$ is given as:

$$
I_{j}(t+1)-I_{j}(t)=\frac{\beta_{j}(t) S_{j}(t)}{N_{j}} I(t)-\gamma_{j}(t) I_{j}(t)
$$

Solving for $\beta_{j}(t)$, leads to the following equation,

$$
\beta_{j}(t)=\frac{I_{j}(t+1)-I_{j}(t)}{I_{j}(t)} \frac{N_{j}}{S_{j}(t)}+\gamma_{j}(t) \frac{N_{j}}{S_{j}(t)}
$$

We assume that the recovery rate, $\gamma_{j}(t)$, is constant across time and countries, we set $\gamma=1 / 18$ (following findings in Atkeson (2020) and consistent with the fraction of infected that recovered or died according to the WHO as compiled in JHU CCSE).

Following Chen and Qiu (2020), the impacts of $k$ NPIs in country $j$ are measured as follows,

$$
\beta_{j}(t)=\exp \left(\alpha_{j}+\sum_{k=1}^{K} \delta_{j k} N P I_{j t k}\right) .
$$

where $\alpha_{j}$ is a country fixed effect and

$$
N P I_{j, t, k}= \begin{cases}1 & \text { if } t<t_{k}^{*} \\ \exp \left(-\frac{\left(t-t_{k}^{*}\right)}{\tau}\right) & \text { if } \mid t \geq t_{k}^{*}\end{cases}
$$

where $t_{k}^{*}$ represents the time when the $N P I_{k}$ was enacted. The parameter $\tau$ controls for the time-lag effect of interventions. We assume $\tau=8$, which reflects findings on COVID-19 incubation period. ${ }^{8}$

The differences in the impacts of NPIs across countries, summarized by the $\delta_{j k}$, can reflect a variety of factors. First, there can be differences in compliance rates due to countryspecific characteristics or due to differences in enforcement. For example, higher population density may interfere with the effectiveness of NPIs that impose social distancing and making them less effective. Second, some populations may practice voluntary social distancing more extensively than others prior to the interventions (for example, due to a higher proportion of high risk population). This mechanism implies that in such communities the effect of NPIs that impose social distancing on transmission rate should be less pronounced.

Allowing the impacts of NPIs to vary with country-specific characteristics, the empirical specification of equation (4) takes the following form,

$$
\log \beta_{j t}=\alpha_{0 j}+\sum_{k=1}^{K} \alpha_{1 k} N P I_{j t k}+\sum_{k=1}^{K} \alpha_{2 k} \mathbb{Z}_{j} N P I_{j t k}+\epsilon_{j t},
$$

\footnotetext{
${ }^{8}$ For example, Lauer et al. (2020) and Linton et al. (2020) that find that incubation period of COVID-19 is 5.2 days on average; $\mathrm{Li}$ at al. (2020) reports 4.1 to 7.0 days; and Wu et al. (2020a) find this period to be 6.1 days. Combining the length of the incubation period with feeling symptoms, being tested and results reported, we set the time-lag effect of interventions at 8 days.
} 
where vector $\mathbb{Z}_{j}$ includes a range of country specific characteristics, including aggregate health variables: health spending as a \% of GDP, number of physicians per 1000 people, and the proportion of population above 65; economic indicators: log GDP per capita and ratio of employed in population; environmental indicators: $\log$ of surface area, population density (people per $\mathrm{km}^{2}$ ), and air pollution measured (concentration of PM2.5). Measurement error in the data is denoted by $\epsilon_{j t}$.

To estimate (6), we focus on a selected set of NPIs. Including all NPIs presents an identification challenge since there are high correlations between implementations and timings of different policies. Appendix Table 6 shows that policies follow very tightly; for example, the policies of workplace closures, "stay-at-home" orders, restrictions of public gatherings and public transport closures are all implemented within five days, on average. Therefore, we focus on major policies that enforce social distancing, schools and workplaces closures while controlling for the "stay-at-home" policy, and extensive testing policy. The period for the estimation is between 7 days before the first "major" NPI until country $j$ begins to relax its policies, where "major" NPIs include schools or/end workplace closures.

Table 1 reports fixed effects estimation results of Eq. 6. Extensive testing (ET) is more effective in countries with higher GDP per capita, larger surface area, higher air pollution, lower health expenditure (as \% of GDP), and higher proportion of older population (65 plus). On the other hand, the schools and workplace closures policies are more effective in countries with higher GDP per capita, lower population density, smaller surface area, lower pollution, lower employment rate, higher health expenditure and lower proportion of older population.

Appendix Table 8 reports estimation results of Eq. 6 using observations for all available countries and shows similar results. In Appendix Table 9 we report fixed effects estimation results of Eq. 6 using the alternative measure of COVID-19 cases, which we construct using the death toll. ${ }^{9}$ The estimations show similar relationships between the impacts of schools and workplace closures policies and country-level characteristics on transmission rates.

We test for robustness of the findings using an alternative measure of government response, the The OxCGRT Stringency Index $(S I)$. We estimate how the relationship between $S I$ and transmission rate varies with country-specific characteristics using the following specification,

$$
\log \beta_{j t}=\gamma_{0}+\gamma_{1} S I_{j t}+\mathbb{Z}_{j} \gamma_{2} S I_{j t}+\varepsilon_{j t},
$$

\footnotetext{
${ }^{9}$ As an alternative measure to COVID-19 records, we derive an estimate based on fatalities record. First, we calculate the average fatality duration, i.e., the number of days between the case being reported and death. To calculate this duration we use the main subsample, and calculate the number of days between the peak reported new cases and peak reported new deaths. This calculation excludes countries where peak new daily cases was after peak new daily deaths (26 countries). We also exclude countries with very high calculated duration of above 60 days (one country). The former restriction is based on the assumption that the peak of daily death toll should not occur before the peak of daily cases occurs. Given that mortality outcome is systematic, we should observe that more cases lead to higher death toll. Therefore, we assume that reaching a daily mortality peak before daily cases peak is likely to be explained by undercounting of daily cases. We find the average duration to be 14 days from the day the case was reported. We construct the alternative count of COVID-19 cases using 1\% mortality rate from COVID-19 and 14 days fatality duration. The mortality rate of $1 \%$ is an average which is reported in a number of studies, see for example Fernandez-Villaverde and Jones (2020).
} 


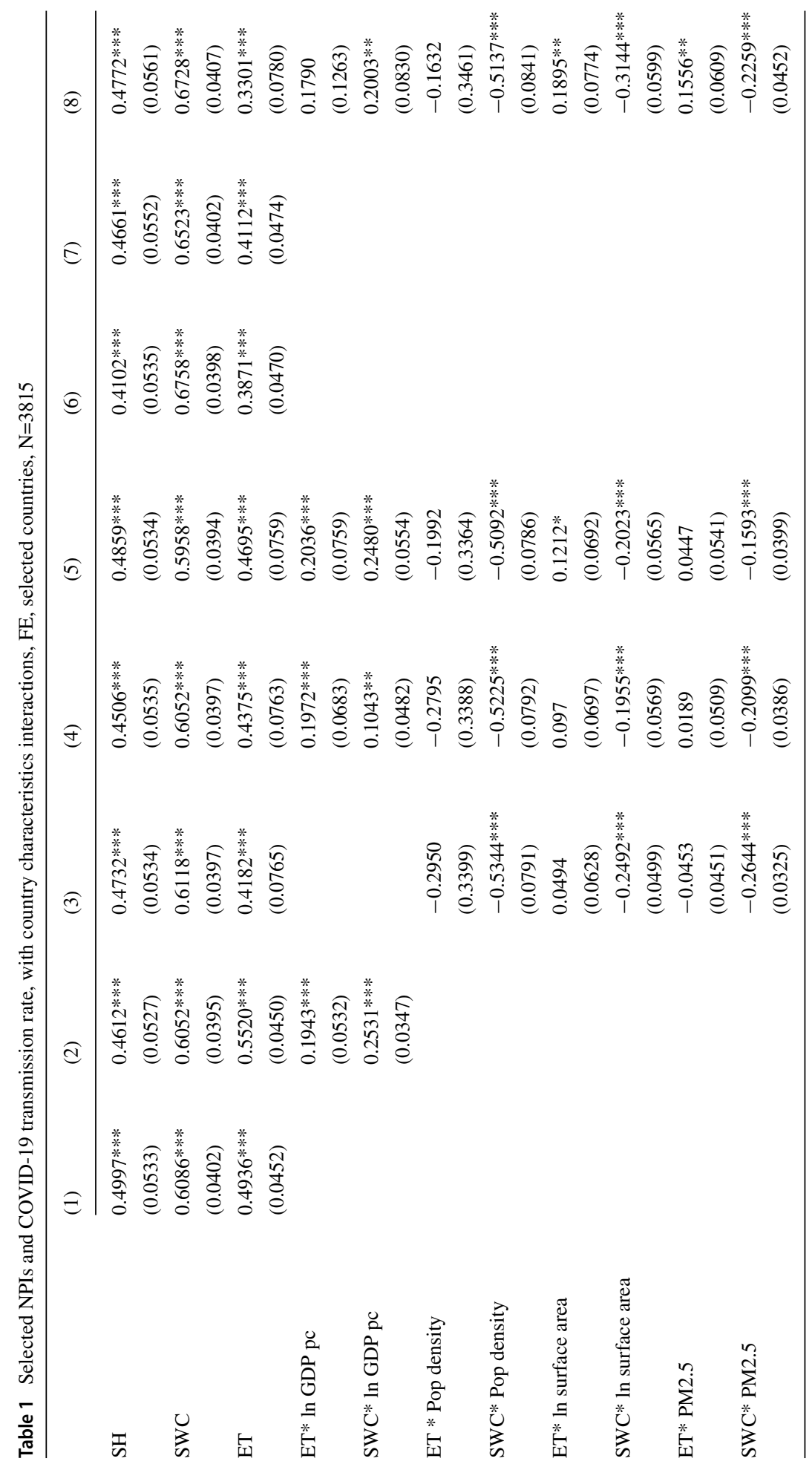




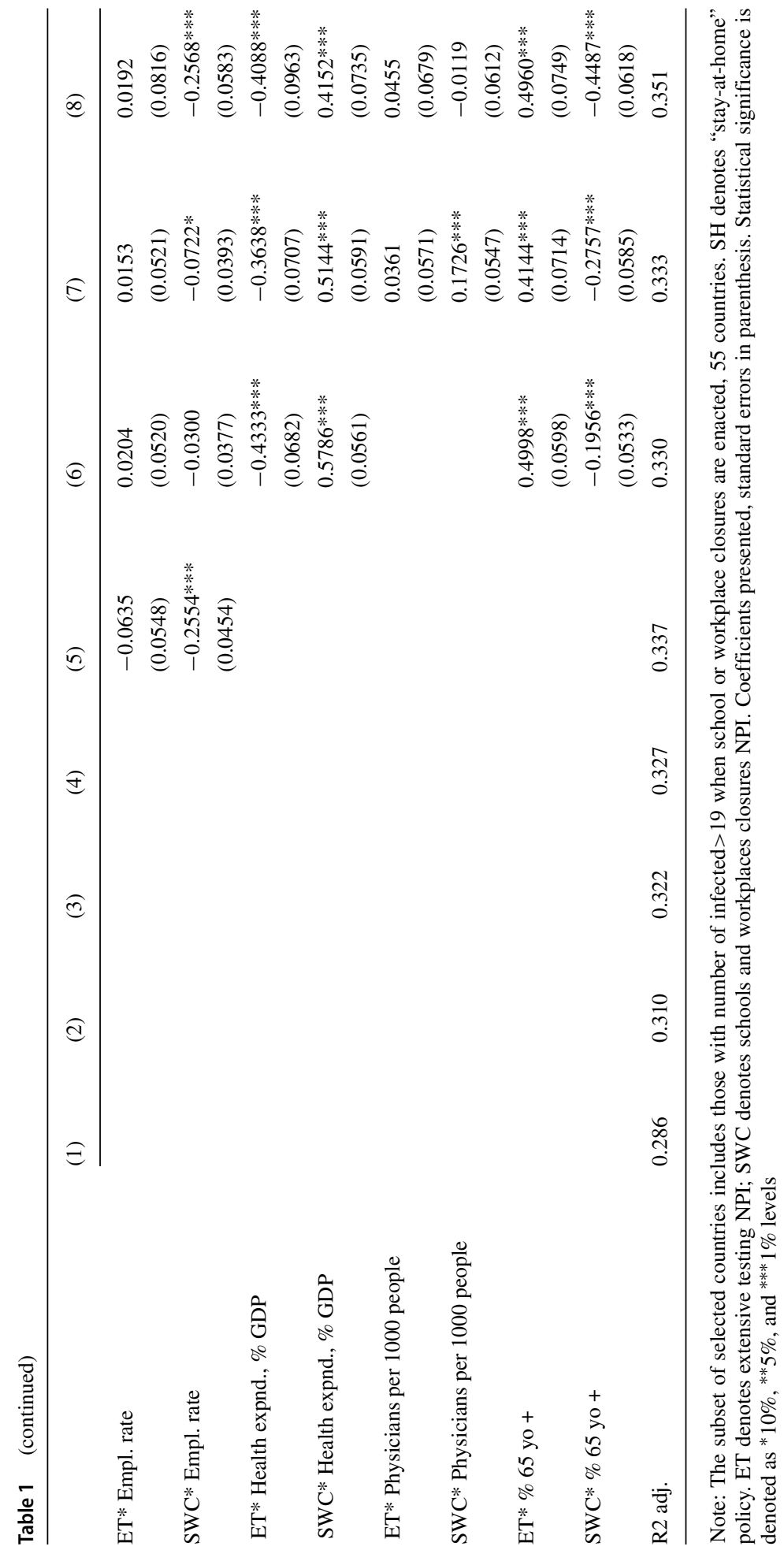


the measure of $S I_{j} t$ accounts for the lag between the policy and its effect on the transmission rate by using the average $S I$ of prior 12 to 5 days. The estimation is limited to the periods where the $S I$ is increasing. ${ }^{10}$

Table 2 reports the results. Negative coefficients imply higher impact of the policies. Column (1) shows that there is a negative correlation between $S I$ and transmission rate. Columns (2)-(6) gradually introduce aggregate country-specific controls. The patterns are similar to those reported in Table 1. The effectiveness of policies is declining with population density and surface area; and increasing with health expenditure and proportion of physicians in population.

\section{Internal mobility}

To further investigate the cross-country differences in transmission rates, we analyze the variation in internal mobility (from Google Mobility Reports data). First, using the sample of all countries, we estimate how internal mobility varies before NPIs are enacted, focusing on five location categories: residential areas, retail and restaurants, public transit stations, parks and beaches, and workplaces. We use the following specification,

$$
M I_{i j t}=\lambda_{i 0}+\lambda_{i 1}\left(t-t^{*}\right)+\mathbb{Z}_{i j} \lambda_{i 2}+u_{i j t},
$$

where $M I_{i j t}$ is a mobility index for category $i$.

Table 3 reports the results of Eq. 8, where the "before" period is defined as 10 to 6 days before school/workplaces closures. ${ }^{11}$ Mobility changes vary across countries; in the period immediately before the implementation of major social distancing NPIs, people spend relatively less time in residential areas (i.e., at home) in countries with higher proportion of physicians, higher health spendings, higher employment and lower GDP per capita.

The empirical model of response of internal mobility to the major NPIs is specified as follows,

$$
M I_{i j t}=\mu_{i 0}+\sum_{k=1}^{K} \mu_{i 1 k} \mathbb{I}_{j t k}+\sum_{k=1}^{K} \mu_{i 2 k} \mathbb{Z}_{j} \mathbb{I}_{j t k}+\epsilon_{i j t},
$$

where $\mathbb{I}_{j t k}$ is a binary indicator of policy $k .{ }^{12}$ We estimate (9) using information between 7 days before and 7 days after the school or workplace closures. We focus on this short time period because of the relationship between mobility and transmission rates. Individuals

\footnotetext{
${ }^{10}$ The theory shows that the introduction of NPIs reduces the transmission rate. We assume that NPIs are introduced when the transmission is out of control and when untraced community transmission is present. Eliminating some NPIs (for example, opening schools when country borders are still closed) does not necessarily increase the transmission rate provided that cases are under control and known.

${ }^{11}$ Due to measurement errors considerations, we exclude the few days just before the policies were enacted. The before period may cover days on which government information campaigns, contact tracing of infected, and some restrictions on international travel were in place. See Appendix Table 6 for average timings of various NPIs.

${ }^{12}$ In Eq. 9 we include a binary policy indicator and not "gradual" indicators as in Eqs. 6 and 7. This is because government restrictions should have an immediate effect on human mobility; however, when estimating the change in transmission rate, we allow for a delay in effect because the detection of cases following an incubation and showing symptoms period takes 8 days on average.
} 


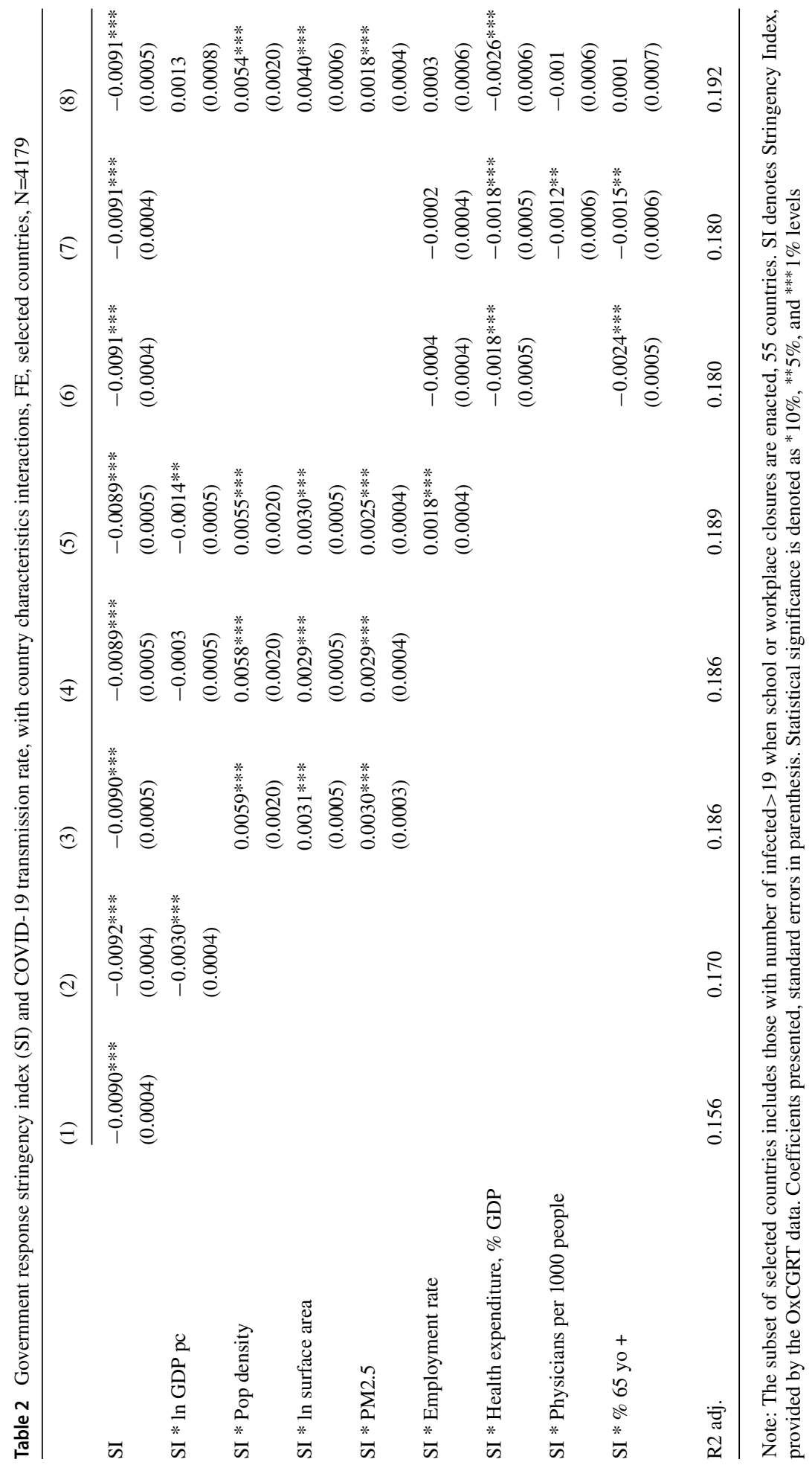


Table 3 Change in daily Google mobility indexes before selected NPIs and aggregate measures, OLS, N=235

\begin{tabular}{|c|c|c|c|c|c|}
\hline & $\begin{array}{l}\text { places of } \\
\text { residence }\end{array}$ & $\begin{array}{c}\text { shopping \& } \\
\text { restaurants }\end{array}$ & $\begin{array}{l}\text { transit } \\
\text { stations }\end{array}$ & $\begin{array}{l}\text { parks and } \\
\text { beaches }\end{array}$ & workplaces \\
\hline & (1) & (2) & (3) & (4) & (5) \\
\hline \# days to major closure NPI & $\begin{array}{l}0.0914 \\
(0.0774)\end{array}$ & $\begin{array}{l}-0.3207^{* *} \\
(0.1551)\end{array}$ & $\begin{array}{l}-0.4645^{*} \\
(0.2771)\end{array}$ & $\begin{array}{l}-0.1723 \\
(0.4195)\end{array}$ & $\begin{array}{l}-0.1019 \\
(0.3946)\end{array}$ \\
\hline $\ln$ GDP pc & $\begin{array}{l}1.1099 * * * \\
(0.2997)\end{array}$ & $\begin{array}{l}-0.1742 \\
(0.8476)\end{array}$ & $\begin{array}{l}-1.16 \\
(1.1784)\end{array}$ & $\begin{array}{l}1.4256 \\
(1.8511)\end{array}$ & $\begin{array}{l}-3.8609 * * * \\
(1.3516)\end{array}$ \\
\hline Pop density & $\begin{array}{l}0.2723 \\
(1.4921)\end{array}$ & $\begin{array}{l}0.5787 \\
(3.9787)\end{array}$ & $\begin{array}{l}3.8465 \\
(5.4378)\end{array}$ & $\begin{array}{l}-3.8104 \\
(8.0098)\end{array}$ & $\begin{array}{l}1.3329 \\
(7.0940)\end{array}$ \\
\hline ln surface area & $\begin{array}{l}-0.2236 \\
(0.3072)\end{array}$ & $\begin{array}{l}1.6819 * * \\
(0.6836)\end{array}$ & $\begin{array}{l}1.8664 \\
(1.2862)\end{array}$ & $\begin{array}{l}2.0209 \\
(1.3936)\end{array}$ & $\begin{array}{l}1.9851 \\
(1.5807)\end{array}$ \\
\hline PM2.5 & $\begin{array}{l}-0.2612 \\
(0.2847)\end{array}$ & $\begin{array}{l}0.7722 \\
(0.6046)\end{array}$ & $\begin{array}{l}0.5222 \\
(1.1507)\end{array}$ & $\begin{array}{l}2.7549 * * \\
(1.1089)\end{array}$ & $\begin{array}{l}0.7442 \\
(1.2185)\end{array}$ \\
\hline Employment rate & $\begin{array}{l}-0.4626^{*} \\
(0.2327)\end{array}$ & $\begin{array}{l}-0.2225 \\
(0.5887)\end{array}$ & $\begin{array}{l}-0.3846 \\
(0.8753)\end{array}$ & $\begin{array}{l}-0.2511 \\
(0.9967)\end{array}$ & $\begin{array}{l}1.8284 \\
(1.1259)\end{array}$ \\
\hline Health expend, \% GDP & $\begin{array}{l}-0.4264 * * \\
(0.2133)\end{array}$ & $\begin{array}{l}-0.8635 \\
(0.6525)\end{array}$ & $\begin{array}{l}-0.5758 \\
(0.9658)\end{array}$ & $\begin{array}{l}-0.6645 \\
(1.4881)\end{array}$ & $\begin{array}{l}0.9588 \\
(1.1111)\end{array}$ \\
\hline Physicians & $\begin{array}{l}-0.7330^{* *} \\
(0.3247)\end{array}$ & $\begin{array}{l}0.3229 \\
(1.0149)\end{array}$ & $\begin{array}{l}1.8919 \\
(1.5030)\end{array}$ & $\begin{array}{l}-1.304 \\
(2.3236)\end{array}$ & $\begin{array}{l}2.4154 \\
(1.6649)\end{array}$ \\
\hline$\% 65$ yо + & $\begin{array}{l}0.1165 \\
(0.3344)\end{array}$ & $\begin{array}{l}0.9046 \\
(0.9230)\end{array}$ & $\begin{array}{l}0.0773 \\
(1.4559)\end{array}$ & $\begin{array}{l}3.4031 \\
(2.3996)\end{array}$ & $\begin{array}{l}-1.2199 \\
(1.7227)\end{array}$ \\
\hline const & $\begin{array}{l}1.1428 \\
(0.8653)\end{array}$ & $\begin{array}{l}-2.1179 \\
(1.4903)\end{array}$ & $\begin{array}{l}-3.0578 \\
(2.8041)\end{array}$ & $\begin{array}{l}0.0028 \\
(3.9462)\end{array}$ & $\begin{array}{l}2.4873 \\
(4.0568)\end{array}$ \\
\hline R2 adj. & 0.118 & 0.116 & 0.088 & 0.074 & 0.107 \\
\hline
\end{tabular}

Note: Google mobility data shows how visitors to (or time spent in) categorized places change compared to the baseline days. A baseline day represents a normal value for that day of the week. The baseline day is the median value from the 5-week period Jan 3 - Feb 6, 2020. The estimations use observations for 10 to 6 days before work or school closures. Variable "\# days to major closure NPI" measures the number of days before schools or workplaces closures. Coefficients presented, standard errors clustered at the country level are in parenthesis. Statistical significance is denoted as *10\%, ${ }^{* * 5 \%}$, and ${ }^{* * *} 1 \%$ levels

make mobility decisions based on the threat of infection, we assume that this threat is relatively stable in the selected short period because of the delayed effect of social distancing NPIs on transmission rates (due to incubation and detection periods). ${ }^{13}$

First, we estimate (9) excluding country-specific controls. Results in Table 4 show a strong relationship between the NPIs and internal mobility. In the period immediately after the implementation of major social distancing NPIs, time spent in residential areas is

\footnotetext{
${ }^{13}$ See, for example, Glaeser et al. (2020) who report that the total COVID-19 cases per capita decrease by around $20 \%-27 \%$ for every ten percentage point fall in mobility and also discuss how infection rate affects mobility.
} 
Table 4 Post-NPIs changes in Google mobility indexes, selected countries, FE

\begin{tabular}{|c|c|c|c|c|c|}
\hline & $\begin{array}{l}\text { All countrie } \\
\text { places of } \\
\text { residence }\end{array}$ & $\begin{array}{l}=1582 \\
\text { shopping \& } \\
\text { restaurants }\end{array}$ & $\begin{array}{l}\text { transit } \\
\text { stations }\end{array}$ & $\begin{array}{l}\text { parks and } \\
\text { beaches }\end{array}$ & workplaces \\
\hline & (1) & (2) & (3) & (4) & (5) \\
\hline $\mathrm{SH}\{0,1\}$ & $\begin{array}{l}1.6215^{* *} \\
(0.6368)\end{array}$ & $\begin{array}{l}-2.7545 \\
(1.8019)\end{array}$ & $\begin{array}{l}-4.1518^{* * *} \\
(1.6695)\end{array}$ & $\begin{array}{l}-7.8930 * * * \\
(2.1789)\end{array}$ & $\begin{array}{l}-1.8717 \\
(1.6668)\end{array}$ \\
\hline ET $\{0,1\}$ & $\begin{array}{l}7.5391 * * * \\
(0.3070)\end{array}$ & $\begin{array}{l}-21.2071 * * * \\
(0.8675)\end{array}$ & $\begin{array}{l}-21.7219^{* * *} \\
(0.8038)\end{array}$ & $\begin{array}{l}-9.9481 * * * \\
(1.0491)\end{array}$ & $\begin{array}{l}-17.6000^{* * * *} \\
(0.8025)\end{array}$ \\
\hline $\operatorname{SWC}\{0,1\}$ & $\begin{array}{l}6.6051 * * * \\
(0.5233)\end{array}$ & $\begin{array}{l}-21.2127 * * * \\
(1.4803)\end{array}$ & $\begin{array}{l}-20.4430^{* * * *} \\
(1.3716)\end{array}$ & $\begin{array}{l}-13.1386^{* * *} \\
(1.7900)\end{array}$ & $\begin{array}{l}-15.3323 * * * \\
(1.3694)\end{array}$ \\
\hline const & $\begin{array}{l}0.3677 \\
(0.2327)\end{array}$ & $\begin{array}{l}0.8283 \\
(0.6592)\end{array}$ & $\begin{array}{l}0.1848 \\
(0.6108)\end{array}$ & $\begin{array}{l}4.1406 * * * \\
(0.7971)\end{array}$ & $\begin{array}{l}3.2229 * * * \\
(0.6098)\end{array}$ \\
\hline \multirow[t]{2}{*}{ R2 adj. } & 0.631 & 0.614 & 0.673 & 0.51 & 0.564 \\
\hline & \multicolumn{5}{|c|}{ Selected countries, $N=931$} \\
\hline $\mathrm{SH}\{0,1\}$ & $\begin{array}{l}0.5864 \\
(0.8072)\end{array}$ & $\begin{array}{l}-1.9945 \\
(2.2634)\end{array}$ & $\begin{array}{l}-2.1676 \\
(2.0371)\end{array}$ & $\begin{array}{l}-7.3590 * * \\
(3.0097)\end{array}$ & $\begin{array}{l}-0.3677 \\
(2.1125)\end{array}$ \\
\hline $\mathrm{ET}\{0,1\}$ & $\begin{array}{l}7.6327 * * * \\
(0.4191)\end{array}$ & $\begin{array}{l}-22.0680 * * * \\
(1.1751)\end{array}$ & $\begin{array}{l}-22.3571 * * * \\
(1.0576)\end{array}$ & $\begin{array}{l}-7.0286 * * * \\
(1.5625)\end{array}$ & $\begin{array}{l}-17.1323 * * * \\
(1.0967)\end{array}$ \\
\hline $\operatorname{SWC}\{0,1\}$ & $\begin{array}{l}4.7763 * * * \\
(0.7506)\end{array}$ & $\begin{array}{l}-18.2815 * * * \\
(2.1047)\end{array}$ & $\begin{array}{l}-18.8988^{* * * *} \\
(1.8943)\end{array}$ & $\begin{array}{l}-9.8070 * * * \\
(2.7987)\end{array}$ & $\begin{array}{l}-13.0276 * * * \\
(1.9644)\end{array}$ \\
\hline const & $\begin{array}{l}0.9485^{* * *} \\
(0.3016)\end{array}$ & $\begin{array}{l}0.046 \\
(0.8456)\end{array}$ & $\begin{array}{l}-0.7575 \\
(0.7611)\end{array}$ & $\begin{array}{l}4.5952 * * * \\
(1.1244)\end{array}$ & $\begin{array}{l}1.6519 * * \\
(0.7892)\end{array}$ \\
\hline $\mathrm{R} 2$ adj. & 0.618 & 0.590 & 0.653 & 0.432 & 0.535 \\
\hline
\end{tabular}

Note: The subset of "all countries" includes 88 countries. The subset of selected countries includes those with number of infected $>19$ when school or workplace closures are enacted, N=48. Google mobility data shows how visitors to (or time spent in) categorized places change compared to the baseline days. A baseline day represents a normal value for that day of the week. The baseline day is the median value from the 5week period Jan 3 - Feb 6, 2020. ET denotes extensive testing NPI; SWC denotes schools and/or workplaces closures; SH denotes "stay-at-home" NPI. Coefficients presented, standard errors in parenthesis. Statistical significance is denoted as ${ }^{*} 10 \%,{ }^{* *} 5 \%$, and ${ }^{* * *} 1 \%$ levels

increasing when social distancing policies are enacted; whereas time spent on retail shopping, recreation, travel and work is declining. Table 5 reports estimation results of Eq. 9. The decline in time spent on activities in non-residential areas reflects the effectiveness of NPIs; it is higher in countries with lower proportion of older population, higher proportion of physicians, lower expenditure on health, lower employment rate, and smaller surface area. These findings are consistent with results in Table 1, where we estimate the relationship between social distancing NPIs and transmission rate. ${ }^{14}$

\section{Discussion and Conclusion}

Governments around the world have responded to the COVID-19 crisis with a range of NPIs aiming to flatten the spread of the virus. Recent studies show that such policies are effective in reducing the spread of the virus. However, it is not determined whether the same

\footnotetext{
${ }^{14}$ Table 5 reports results for all available countries. Appendix Table 10 reports estimation results of Eq. 9 for a subset of selected countries used to produce Table 1; the results are similar.
} 
combination of NPIs is optimal for each country, or whether country specific characteristics should dictate which policies should be implemented or how they should be implemented. This paper aims to fill this gap by studying the interactions between the effectiveness of NPIs at a country-level and country-specific characteristics.

Table 5 Post-NPIs changes in daily Google mobility indexes, with country characteristics interactions, FE, all countries, $\mathrm{N}=1582$

\begin{tabular}{|c|c|c|c|c|c|}
\hline & $\begin{array}{l}\text { places of } \\
\text { residence }\end{array}$ & $\begin{array}{c}\text { shopping \& } \\
\text { restaurants }\end{array}$ & $\begin{array}{l}\text { transit } \\
\text { stations }\end{array}$ & $\begin{array}{l}\text { parks and } \\
\text { beaches }\end{array}$ & workplaces \\
\hline & (1) & (2) & (3) & (4) & $(5)$ \\
\hline $\mathrm{SH}\{0,1\}$ & $\begin{array}{l}6.5930 * * * \\
(0.5290)\end{array}$ & \multicolumn{4}{|c|}{$-21.4214 * * *-19.8816^{* * *}-15.5681 * * *-15.4178 * * *$} \\
\hline ET $\{0,1\}$ & $\begin{array}{l}2.2441 * * \\
(1.1211)\end{array}$ & $\begin{array}{l}-5.8202 * \\
(3.1722)\end{array}$ & $\begin{array}{l}-4.6262 \\
(2.9444)\end{array}$ & $\begin{array}{l}-5.3257 \\
(3.9414)\end{array}$ & $\begin{array}{l}-3.6612 \\
(2.9677)\end{array}$ \\
\hline $\operatorname{SWC}\{0,1\}$ & $\begin{array}{l}8.6343 * * * \\
(0.3171)\end{array}$ & \multicolumn{4}{|c|}{$-23.2667 * * *-23.4267 * * *-12.7039 * * *-20.1859 * * *$} \\
\hline $\mathrm{ET}\{0,1\} * \ln \mathrm{GDP}$ pc & $\begin{array}{l}-1.5158 \\
(1.4852)\end{array}$ & $\begin{array}{l}4.1972 \\
(4.2025)\end{array}$ & $\begin{array}{l}-0.7336 \\
(3.9007)\end{array}$ & $\begin{array}{l}-4.6578 \\
(5.2215)\end{array}$ & $\begin{array}{l}2.6772 \\
(3.9315)\end{array}$ \\
\hline $\operatorname{SWC}\{0,1\}^{*} \ln$ GDP pc & $\begin{array}{l}0.7065 \\
(0.5142)\end{array}$ & $\begin{array}{l}0.858 \\
(1.4550)\end{array}$ & $\begin{array}{l}-1.5153 \\
(1.3505)\end{array}$ & $\begin{array}{l}4.7728 * * * \\
(1.8078)\end{array}$ & $\begin{array}{l}-1.5192 \\
(1.3612)\end{array}$ \\
\hline ET $\{0,1\} *$ Pop density & $\begin{array}{l}-4.5089 \\
(5.2793)\end{array}$ & $\begin{array}{l}13.1933 \\
(14.9403)\end{array}$ & $\begin{array}{l}18.1349 \\
(13.8677)\end{array}$ & $\begin{array}{l}-1.3452 \\
(18.5631)\end{array}$ & $\begin{array}{l}6.5612 \\
(13.9771)\end{array}$ \\
\hline SWC $\{0,1\} *$ Pop density & $\begin{array}{l}1.133 \\
(0.7348)\end{array}$ & $\begin{array}{l}1.0448 \\
(2.0769)\end{array}$ & $\begin{array}{l}3.6166^{*} \\
(1.9278)\end{array}$ & $\begin{array}{l}-1.0372 \\
(2.5806)\end{array}$ & $\begin{array}{l}-2.1305 \\
(1.9430)\end{array}$ \\
\hline ET $\{0,1\} * \ln$ surface area & $\begin{array}{l}-1.4672 \\
(1.3305)\end{array}$ & $\begin{array}{l}0.3524 \\
(3.7653)\end{array}$ & $\begin{array}{l}1.9539 \\
(3.4949)\end{array}$ & $\begin{array}{l}-1.4346 \\
(4.6783)\end{array}$ & $\begin{array}{l}3.3944 \\
(3.5225)\end{array}$ \\
\hline SWC $\{0,1\} * \ln$ surface area & $\begin{array}{l}-2.3717 * * \\
(0.3706)\end{array}$ & $\begin{array}{c}* 8.1015 \text { **** } \\
(1.0430)\end{array}$ & $\begin{array}{l}7.3160 * * * \\
(0.9681)\end{array}$ & $\begin{array}{l}5.0127 * * * \\
(1.2959)\end{array}$ & $\begin{array}{l}6.0197 * * * \\
(0.9757)\end{array}$ \\
\hline ET $\{0,1\} *$ PM 2.5 & $\begin{array}{l}-1.9791 * \\
(1.1413)\end{array}$ & $\begin{array}{l}2.3528 \\
(3.2297)\end{array}$ & $\begin{array}{l}4.772 \\
(2.9978)\end{array}$ & $\begin{array}{l}10.6139 * * * \\
(4.0128)\end{array}$ & $\begin{array}{l}4.104 \\
(3.0215)\end{array}$ \\
\hline $\operatorname{SWC}\{0,1\} * \mathrm{PM} 2.5$ & $\begin{array}{l}-2.6580^{* *} \\
(0.3192)\end{array}$ & $\begin{array}{c}* 4.6792 * * * \\
(0.9033)\end{array}$ & $\begin{array}{l}4.5335 * * * \\
(0.8385)\end{array}$ & $\begin{array}{l}3.6869 * * * \\
(1.1224)\end{array}$ & $\begin{array}{l}6.1490 * * * \\
(0.8451)\end{array}$ \\
\hline ET $\{0,1\}^{*}$ Empl. rate & $\begin{array}{l}-0.1424 \\
(1.2421)\end{array}$ & $\begin{array}{l}-5.193 \\
(3.5151)\end{array}$ & $\begin{array}{l}-2.9941 \\
(3.2627)\end{array}$ & $\begin{array}{l}0.4974 \\
(4.3675)\end{array}$ & $\begin{array}{l}1.4675 \\
(3.2885)\end{array}$ \\
\hline SWC $\{0,1\}^{*}$ Empl. rate & $\begin{array}{l}-0.9886^{* * *} \\
(0.3638)\end{array}$ & $\begin{array}{c}* 3.9615 * * * \\
(1.0282)\end{array}$ & $\begin{array}{l}3.2151 * * * \\
(0.9544)\end{array}$ & $\begin{array}{l}2.5259 * * \\
(1.2776)\end{array}$ & $\begin{array}{l}4.1719 * * * \\
(0.9619)\end{array}$ \\
\hline ET $\{0,1\}^{*}$ Health expend. \%GDP & $\begin{array}{l}-0.2805 \\
(1.1750)\end{array}$ & $\begin{array}{l}2.6961 \\
(3.3253)\end{array}$ & $\begin{array}{l}4.1755 \\
(3.0865)\end{array}$ & $\begin{array}{l}-0.1222 \\
(4.1316)\end{array}$ & $\begin{array}{l}0.9763 \\
(3.1109)\end{array}$ \\
\hline SWC $\{0,1\}^{*}$ Health expend. \%GDP & $\begin{array}{l}-0.7943 * * \\
(0.3567)\end{array}$ & $\begin{array}{l}2.0899 * * \\
(1.0095)\end{array}$ & $\begin{array}{l}0.3806 \\
(0.9370)\end{array}$ & $\begin{array}{l}4.8882 * * * \\
(1.2542)\end{array}$ & $\begin{array}{l}1.1686 \\
(0.9444)\end{array}$ \\
\hline ET $\{0,1\} *$ Physicians $/ 1000$ & $\begin{array}{l}4.4913 * * \\
(1.9555)\end{array}$ & $\begin{array}{l}-8.9163 \\
(5.5339)\end{array}$ & $\begin{array}{l}-10.0033^{*} \\
(5.1366)\end{array}$ & $\begin{array}{l}-16.7206 * * \\
(6.8758)\end{array}$ & $\begin{array}{l}-10.9613 * * \\
(5.1772)\end{array}$ \\
\hline SWC $\{0,1\}^{*}$ Physicians $/ 1000$ & $\begin{array}{l}0.8598 \\
(0.5406)\end{array}$ & $\begin{array}{l}-7.2728 * * * \\
(1.5294)\end{array}$ & $\begin{array}{l}-4.2720 * * * \\
(1.4196)\end{array}$ & $\begin{array}{l}-8.1505^{* * *} \\
(1.9002)\end{array}$ & $\begin{array}{l}-2.1567 \\
(1.4308)\end{array}$ \\
\hline
\end{tabular}


Table 5 (continued)

\begin{tabular}{llllll}
\hline & $\begin{array}{l}\text { places of } \\
\text { residence }\end{array}$ & $\begin{array}{c}\text { shopping \& } \\
\text { restaurants }\end{array}$ & $\begin{array}{l}\text { transit } \\
\text { stations }\end{array}$ & $\begin{array}{l}\text { parks and } \\
\text { beaches }\end{array}$ & workplaces \\
\cline { 2 - 5 } & $(1)$ & $(2)$ & $(3)$ & $(4)$ & $(5)$ \\
ET $\{0,1\} * \% 65$ yo + & -2.6676 & 0.9514 & 6.6116 & $20.9118 * * *$ & 4.6088 \\
SWC $\{0,1\} * \% 65$ yo + & $(2.1159)$ & $(5.9879)$ & $(5.5580)$ & $(7.4399)$ & $(5.6019)$ \\
R2 adj. & $-2.6986 * * *$ & $4.6789 * * *$ & $4.7986 * * *$ & $6.5452 * * *$ & $6.0396 * * *$ \\
\hline
\end{tabular}

Note: The subset of "all countries" includes 88 countries. Google mobility data shows how time spent in different location categories changed compared to the baseline days (a normal value for that day of the week in the 5-week period Jan 3 - Feb 6, 2020). ET denotes extensive testing NPI; SWC denotes schools and/or workplaces closures; SH denotes "stay-at-home" NPI. Coefficients presented, standard errors in parenthesis. Statistical significance is denoted as $* 10 \%,{ }^{* *} 5 \%$, and ${ }^{* * *} 1 \%$ levels

We embed NPIs in a dynamic epidemiological SIR model and show empirically how the effectiveness of NPIs varies with country-specific characteristics. The effectiveness of social distancing policies on transmission rates is declining with population density, surface area, pollution, employment rate and proportion of population over 65 years old; and increasing with GDP per capita and health expenditure. The effectiveness of the enhanced testing policy is increasing with GDP per capita, surface area, air pollution, proportion of older population; and declining with health expenditure.

Estimations that use the Google mobility data suggest that the behavioral response might be important in explaining the results, but it cannot explain all the differences in the effectiveness of NPIs across countries. Access to a better health system and higher employment rate are negatively correlated with staying at home before the social distancing policies are enacted. After the policies are enacted, we observe larger increases in staying at home in countries with lower proportion of elderly population and higher proportion of physicians. This result is consistent with the cross-country differences in transmission rates. This heterogeneity in the effectiveness of NPIs can be explained by differences in voluntary social distancing which varies with country-specific characteristics. Access to a better public health system may reduce voluntary social distancing due to decreased risks and NPIs designed to enforce social distancing are more effective in such communities. On the other hand, in communities with higher proportions of elderly, who are in a higher risk group to become severely ill, voluntary social distancing might be more prevalent before intervention policies are enacted.

Our behavioral interpretation of the variation in mobility and transmission rates across age and health system related dimensions is consistent with findings in other recent studies. For example, Andersen et al. (2020) compare consumption response to shutdowns using data from Sweden and Denmark. They show that there is a considerable heterogeneity across groups with different levels of infection risk. The effect of shutdowns on spending exhibits a significant age gradient: the effect is negative for young adults (18-29 years) and positive for the oldest group (70+ years). Andersen et al. (2020) conclude that shutdowns decrease the 
total spending of individuals with low health risk. Moreover, they show that the effects are particularly pronounced for categories involving high social proximity such as personal care and social spending. On the other hand, shutdowns increase the total spending of individuals with high health risk. Our findings suggest similar behavioral patterns in a cross-country comparison.

Differences in internal mobility and suggested differences in infection risk perceptions cannot explain the variation in transmission rates with respect to GDP per capita, size of geographical area, and population density. Higher population density, larger geographical area, higher employment rate, and lower GDP per capita are associated with less effective social distancing polices. Previous studies show that the spread of viral diseases is more pronounced in more densely populated areas (see for example, Zachreson et al. 2018) and when economic activity is higher (see for example, Markowitz et al. 2019 and Adda 2016), combining this existing evidence with our new findings suggests that the lower effectiveness might be related to resource requirements and the ability to enforce social distancing policies. ${ }^{15}$

Recent studies propose models of complementarities between social distancing and testing policies. For example, Acemoglu et al. (2020) develop a theoretical model showing that enhanced testing policy can lead to more social activity and less social distancing (since people feel more confident), which may lead to an increase in infections. In Table 1 we show that testing is less effective in countries with higher health expenditure and more effective in countries with higher proportion of elderly population. Within the Acemoglu et al. (2020) model this result suggests that the increase in social activity due to the enhanced testing NPI is more likely to occur in places with more advanced health systems and in places with lower proportions of elderly. ${ }^{16}$ It should also be considered that testing intensity varies across countries. Our results show that testing NPI is more effective in countries with higher GDP per capita, which is in line with the testing intensity assumption. We also find that the effectiveness of testing is increasing with surface area, which suggests that this policy is relatively more efficient in such geographic conditions.

Our results complement earlier epidemiological research and the expanding literature on interactions between behavioral response, economic incentives and epidemiological dynamics during the COVID-19 pandemic. Our analysis also complements recent literature on socio-economic inequalities associated with the COVID-19 crisis. The findings emphasize

\footnotetext{
${ }^{15}$ The relationships between air pollution and the effectiveness of NPIs is subject to a number of factors. On one hand, the positive association between long term exposure to pollutants and reduced lung function suggests that individuals in affected areas should practice social distancing more rigorously, which would imply less efficient social distancing policies. On the other hand, the positive association between airborne transmission of the virus and presence of pollutants suggests that social distancing policies should be more effective in more polluted areas.

${ }^{16}$ We do not find support for these implications in the Google mobility data; there are no consistent statistically significant relationships between country specific characteristics and mobility after testing NPIs are enacted. However, we are using a very short time period around the policy implementation, which should capture the period before the number of new cases reflects the changes in transmission rates (due to incubation period and reporting delays). Thus, the gain in confidence and its effect of number of contacts might be too early to observe.
} 
that the effectiveness of a given NPI policy varies with the socio-economic and geographic characteristics of a given community and highlight that targeted policies may improve the outcomes of government response policies.

\section{Appendix}

Table 6 Timing of NPIs

\begin{tabular}{lll}
\hline & $\begin{array}{l}\text { Number of countries } \\
\text { with given NPI }\end{array}$ & Average starting date \\
\cline { 2 - 3 } Gov information campaign & 132 & $24-$ Feb-20 \\
Movement restrictions & 133 & $26-$ Feb-20 \\
Contact tracing & 59 & 4-Mar-20 \\
International travel restrictions & 132 & 5-Mar-20 \\
Public events cancellations & 134 & $11-$ Mar-20 \\
School closures & 135 & $13-$ Mar-20 \\
Extensive testing & 68 & 14-Mar-20 \\
Workplace closures & 121 & 18-Mar-20 \\
"Stay-at-home" & 50 & $18-$ Mar-20 \\
Restrictions of public gatherings & 132 & 19-Mar-20 \\
Public transport closures & 97 & 22-Mar-20 \\
\hline
\end{tabular}

Note: Source: OxCGRT data. The sample includes 201 countries and territories. The measures include general, targeted and recommended policies. Workplace closures may vary across countries and may include closures of cafes and restaurants, retail, beauty and personal care services, entertainment venues, leisure and recreation, residential facilities, outdoor recreation, non-residential institutions (such as libraries and museums and places of worship)

Table 7 Summary Statistics, selected countries

\begin{tabular}{|c|c|c|c|c|c|c|c|c|c|}
\hline & $\begin{array}{l}\text { Summary } \\
\text { Statistics, } \\
\text { selected } \\
\text { countries }\end{array}$ & $\begin{array}{l}\ln \\
\text { GDP } \\
\text { per } \\
\text { capita } \\
\text { (\$US) }\end{array}$ & $\begin{array}{l}\text { Pop } \\
\text { density, } \\
\text { (people } \\
\text { per sq. } \\
\text { km of } \\
\text { land) }\end{array}$ & $\begin{array}{l}\text { ln sur- } \\
\text { face area } \\
(\mathrm{sq} . \mathrm{km})\end{array}$ & $\begin{array}{l}\text { PM2.5 } \\
\text { air pollu- } \\
\text { tion (mg } \\
\text { per } \mathrm{m} 3 \text { ) }\end{array}$ & $\begin{array}{l}\text { Empl. } \\
\text { to pop. } \\
\text { ratio }\end{array}$ & $\begin{array}{l}\text { Health } \\
\text { expend., } \\
\% \text { GDP }\end{array}$ & $\begin{array}{l}\text { Physicians } \\
\text { per } \\
1000 \text { people }\end{array}$ & $\begin{array}{l}\% 65 \text { уо } \\
+ \text { in pop. }\end{array}$ \\
\hline Algeria & 2160 & 8.47 & 0.18 & 14.68 & 38.88 & 36.91 & 6.65 & 1.52 & 6.10 \\
\hline Argentina & 2443 & 9.21 & 0.16 & 14.84 & 13.31 & 54.10 & 7.55 & 3.69 & 10.92 \\
\hline Australia & 6440 & 10.95 & 0.03 & 15.86 & 8.55 & 62.15 & 9.25 & 3.41 & 15.26 \\
\hline Austria & 14336 & 10.82 & 1.07 & 11.34 & 12.48 & 58.39 & 10.44 & 4.94 & 18.93 \\
\hline Bahrain & 1671 & 9.97 & 20.17 & 6.65 & 70.82 & 70.93 & 4.87 & 0.95 & 2.37 \\
\hline Belgium & 33573 & 10.76 & 3.77 & 10.33 & 12.89 & 50.96 & 10.04 & 3.01 & 18.47 \\
\hline Brazil & 28320 & 9.31 & 0.25 & 15.96 & 12.71 & 54.57 & 11.77 & 1.96 & 8.46 \\
\hline Canada & 28208 & 10.85 & 0.04 & 16.12 & 6.43 & 61.60 & 10.53 & 2.44 & 16.65 \\
\hline Chile & 8273 & 9.62 & 0.25 & 13.54 & 21.04 & 55.51 & 8.53 & 1.08 & 11.05 \\
\hline China & 83356 & 8.96 & 1.48 & 16.07 & 52.66 & 67.66 & 4.98 & 1.60 & 10.10 \\
\hline
\end{tabular}


Table 7 (continued)

Summary ln Pop ln sur- PM2.5 Empl. Health Physicians \%65 yo Statistics, GDP density, face area air pollu- to pop. expend., per + in pop. selected per (people (sq. km) tion (mg ratio \% GDP 1000 people countries capita per sq. per m3)

(\$US) $\mathrm{km}$ of

land)

\begin{tabular}{|c|c|c|c|c|c|c|c|c|c|}
\hline Colombia & 3105 & 8.95 & 0.45 & 13.95 & 16.53 & 62.16 & 5.91 & 1.83 & 8.08 \\
\hline Costa Rica & 626 & 9.20 & 0.98 & 10.84 & 15.73 & 54.43 & 7.56 & 1.15 & 9.11 \\
\hline Croatia & 1741 & 9.67 & 0.73 & 10.94 & 17.90 & 46.87 & 7.18 & 2.97 & 19.83 \\
\hline Czech. Rep. & 6216 & 10.06 & 1.38 & 11.28 & 16.07 & 59.20 & 7.15 & 3.76 & 18.73 \\
\hline Denmark & 6681 & 11.06 & 1.38 & 10.67 & 10.03 & 59.38 & 10.35 & 3.75 & 19.49 \\
\hline Egypt & 2505 & 7.97 & 0.99 & 13.82 & 87.00 & 39.73 & 4.64 & 1.21 & 5.17 \\
\hline Estonia & 1400 & 9.90 & 0.30 & 10.72 & 6.73 & 60.38 & 6.68 & 3.33 & 19.20 \\
\hline Finland & 3237 & 10.79 & 0.18 & 12.73 & 5.86 & 55.07 & 9.49 & 3.20 & 21.01 \\
\hline France & 133470 & 10.68 & 1.22 & 13.22 & 11.81 & 50.74 & 11.54 & 3.20 & 19.47 \\
\hline Germany & 134753 & 10.77 & 2.37 & 12.79 & 12.03 & 59.21 & 11.14 & 3.99 & 21.34 \\
\hline Greece & 2192 & 10.07 & 0.83 & 11.79 & 16.22 & 41.88 & 8.45 & 5.83 & 21.25 \\
\hline Iceland & 1727 & 10.86 & 0.04 & 11.54 & 6.48 & 79.63 & 8.29 & 3.67 & 14.25 \\
\hline Indonesia & 5136 & 8.36 & 1.48 & 14.46 & 16.50 & 64.66 & 3.12 & 0.28 & 5.61 \\
\hline Iran & 76389 & 8.85 & 0.50 & 14.37 & 38.98 & 39.14 & 8.10 & 1.17 & 5.99 \\
\hline Ireland & 12547 & 11.25 & 0.70 & 11.16 & 8.21 & 58.60 & 7.38 & 2.79 & 13.33 \\
\hline Israel & 12501 & 10.46 & 4.11 & 10.00 & 21.38 & 61.37 & 7.31 & 3.30 & 11.60 \\
\hline Italy & 165155 & 10.48 & 2.05 & 12.62 & 16.75 & 44.62 & 8.94 & 3.97 & 22.36 \\
\hline Japan & 8100 & 10.80 & 3.47 & 12.84 & 11.70 & 60.03 & 10.93 & 2.32 & 26.82 \\
\hline Kuwait & 1405 & 10.41 & 2.32 & 9.79 & 60.75 & 72.24 & 3.90 & 2.49 & 2.32 \\
\hline Luxembourg & 3373 & 11.61 & 2.50 & 7.86 & 10.36 & 56.54 & 6.16 & 2.85 & 14.08 \\
\hline Malaysia & 5072 & 9.40 & 0.96 & 12.71 & 16.04 & 66.37 & 3.80 & 1.32 & 6.32 \\
\hline Mexico & 5399 & 9.25 & 0.65 & 14.49 & 20.92 & 57.60 & 5.47 & 2.14 & 6.97 \\
\hline Morocco & 2024 & 8.12 & 0.81 & 13.01 & 32.59 & 42.22 & 5.84 & 0.65 & 6.67 \\
\hline Netherlands & 28153 & 10.92 & 5.11 & 10.63 & 12.03 & 61.82 & 10.36 & 3.29 & 18.57 \\
\hline New Zealand & 1386 & 10.55 & 0.19 & 12.50 & 5.96 & 67.69 & 9.22 & 2.79 & 15.16 \\
\hline Norway & 6740 & 11.43 & 0.15 & 13.21 & 6.96 & 61.68 & 10.50 & 4.35 & 16.70 \\
\hline Oman & 910 & 9.67 & 0.16 & 12.64 & 41.12 & 66.59 & 4.29 & 2.04 & 2.33 \\
\hline Philippines & 5453 & 8.01 & 3.58 & 12.61 & 18.07 & 57.60 & 4.39 & 1.28 & 4.86 \\
\hline Poland & 7582 & 9.72 & 1.24 & 12.65 & 20.88 & 54.17 & 6.52 & 2.26 & 16.63 \\
\hline Portugal & 18091 & 10.09 & 1.12 & 11.43 & 8.16 & 54.98 & 9.08 & 3.97 & 21.36 \\
\hline Qatar & 3711 & 11.06 & 2.40 & 9.36 & 91.19 & 87.95 & 3.08 & 2.12 & 1.18 \\
\hline Romania & 7216 & 9.35 & 0.85 & 12.38 & 14.61 & 52.68 & 4.98 & 2.50 & 17.65 \\
\hline Russia & 24490 & 9.37 & 0.09 & 16.65 & 16.16 & 59.82 & 5.27 & 3.83 & 14.09 \\
\hline Serbia & 4873 & 8.84 & 0.80 & 11.39 & 24.73 & 47.55 & 9.14 & 2.59 & 17.66 \\
\hline Singapore & 3699 & 10.97 & 79.53 & 6.58 & 19.08 & 65.08 & 4.47 & 1.93 & 10.21 \\
\hline Slovenia & 1248 & 10.19 & 1.03 & 9.93 & 16.02 & 55.81 & 8.47 & 2.66 & 18.78 \\
\hline South Africa & 2506 & 8.91 & 0.48 & 14.01 & 25.10 & 40.32 & 8.11 & 0.77 & 5.17 \\
\hline Spain & 177644 & 10.40 & 0.94 & 13.13 & 9.70 & 49.08 & 8.97 & 3.84 & 19.02 \\
\hline Switzerland & 26336 & 11.28 & 2.16 & 10.63 & 10.30 & 65.26 & 12.25 & 4.01 & 18.32 \\
\hline Thailand & 2643 & 8.76 & 1.36 & 13.15 & 26.26 & 67.28 & 3.71 & 0.53 & 11.24 \\
\hline UAE & 5365 & 10.62 & 1.36 & 11.33 & 40.92 & 79.20 & 3.52 & 1.84 & 1.01 \\
\hline UK & 98476 & 10.68 & 2.75 & 12.40 & 10.47 & 60.56 & 9.76 & 2.75 & 18.20 \\
\hline USA & 636350 & 10.91 & 0.36 & 16.10 & 7.41 & 60.42 & 17.07 & 2.53 & 15.23 \\
\hline
\end{tabular}




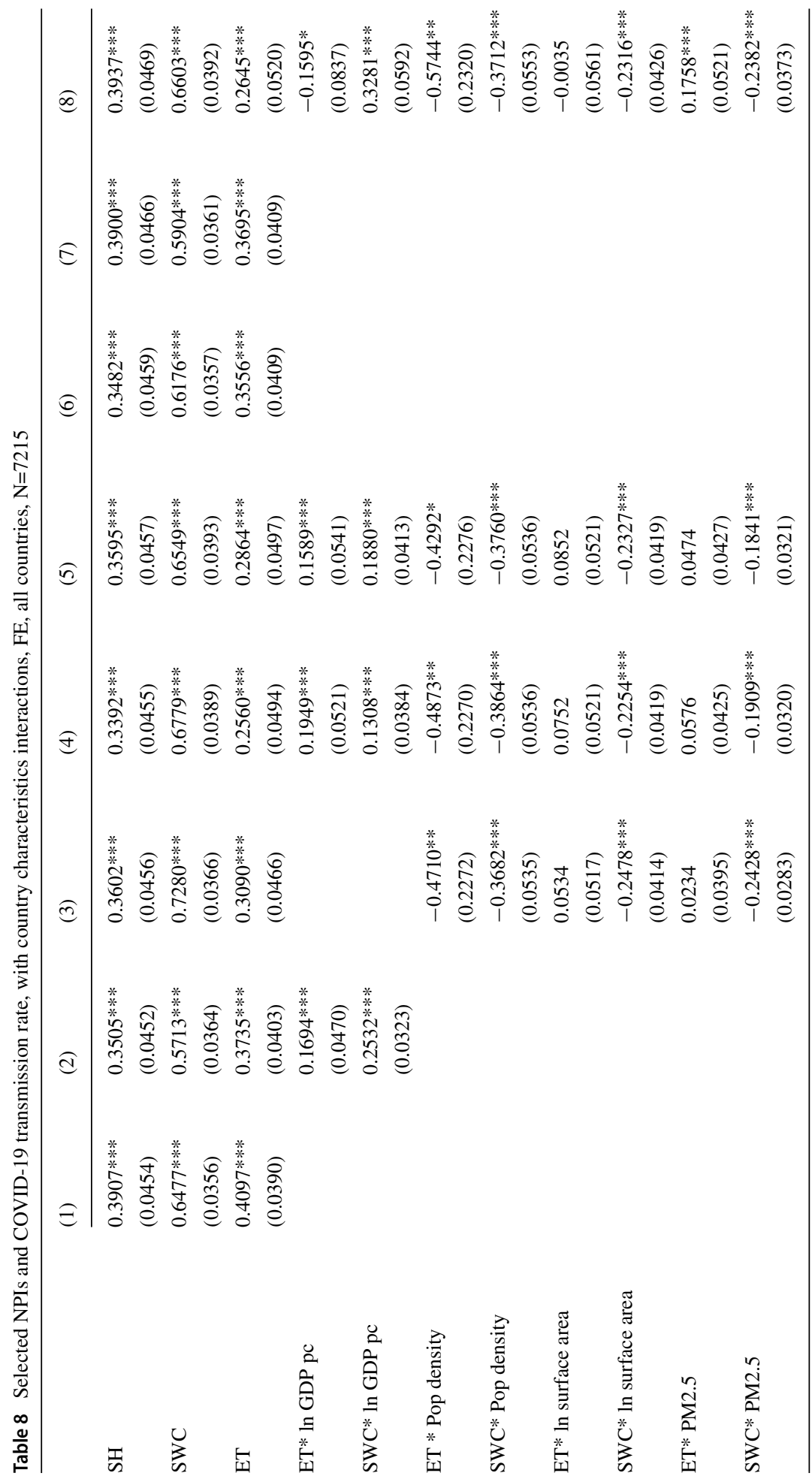




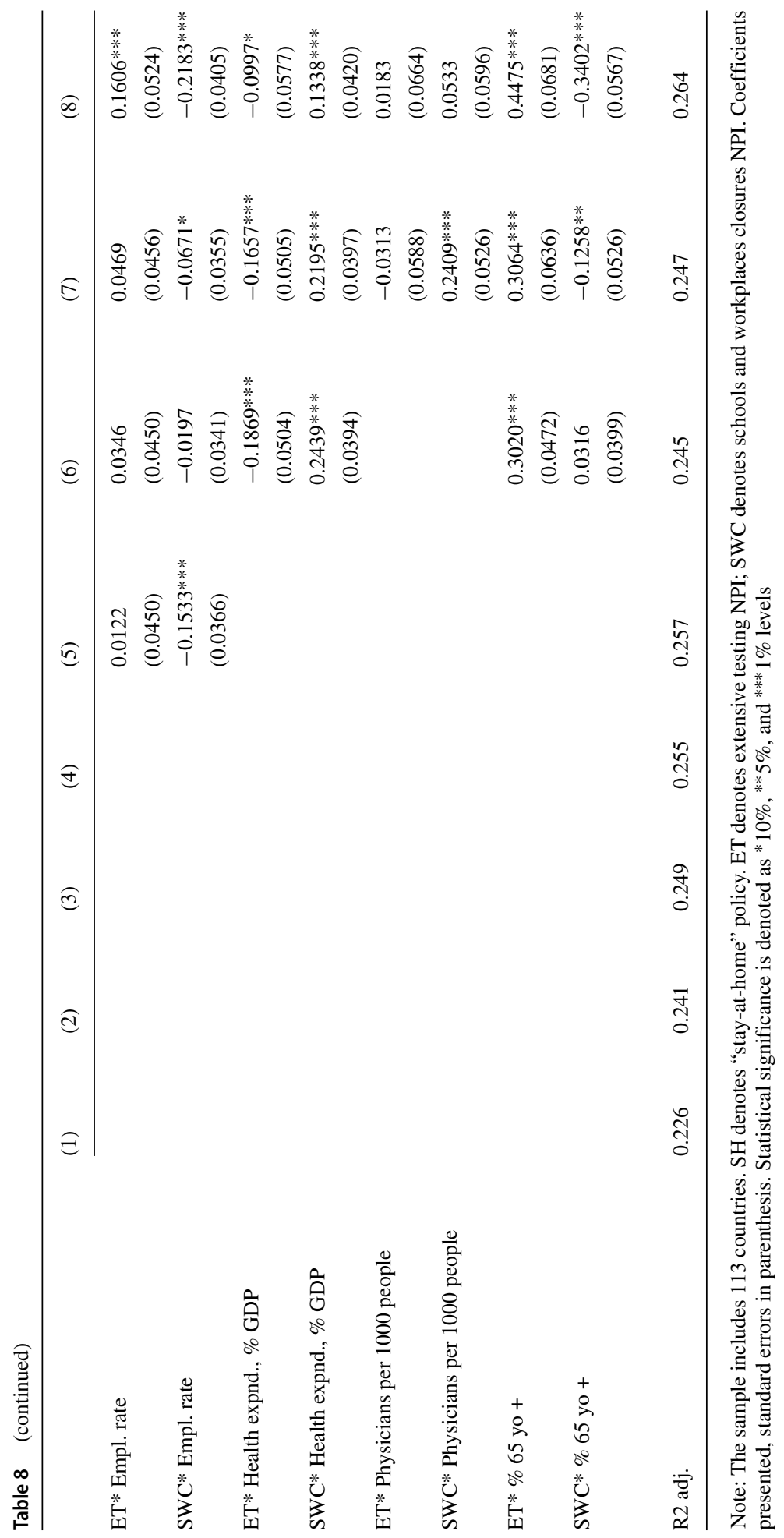




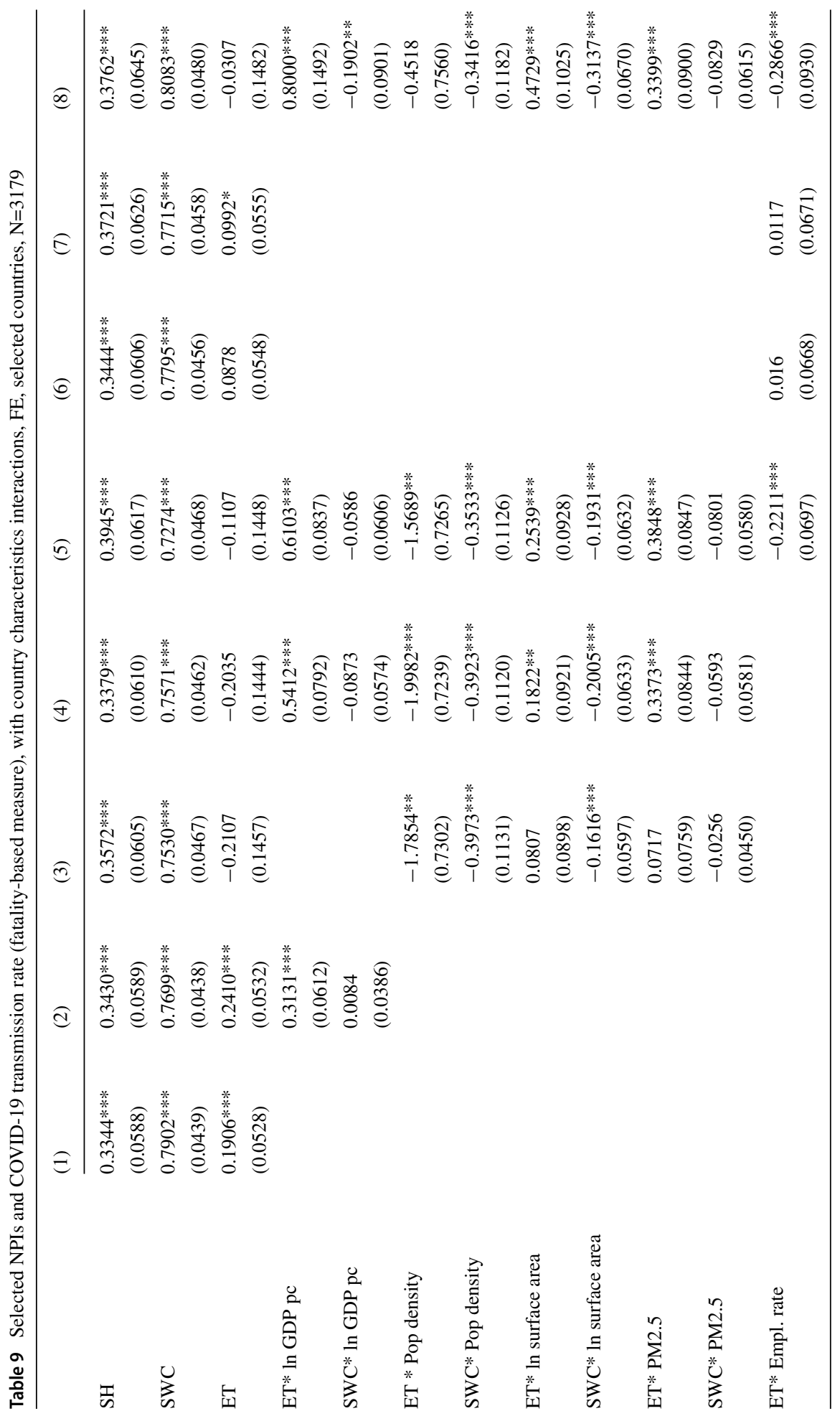




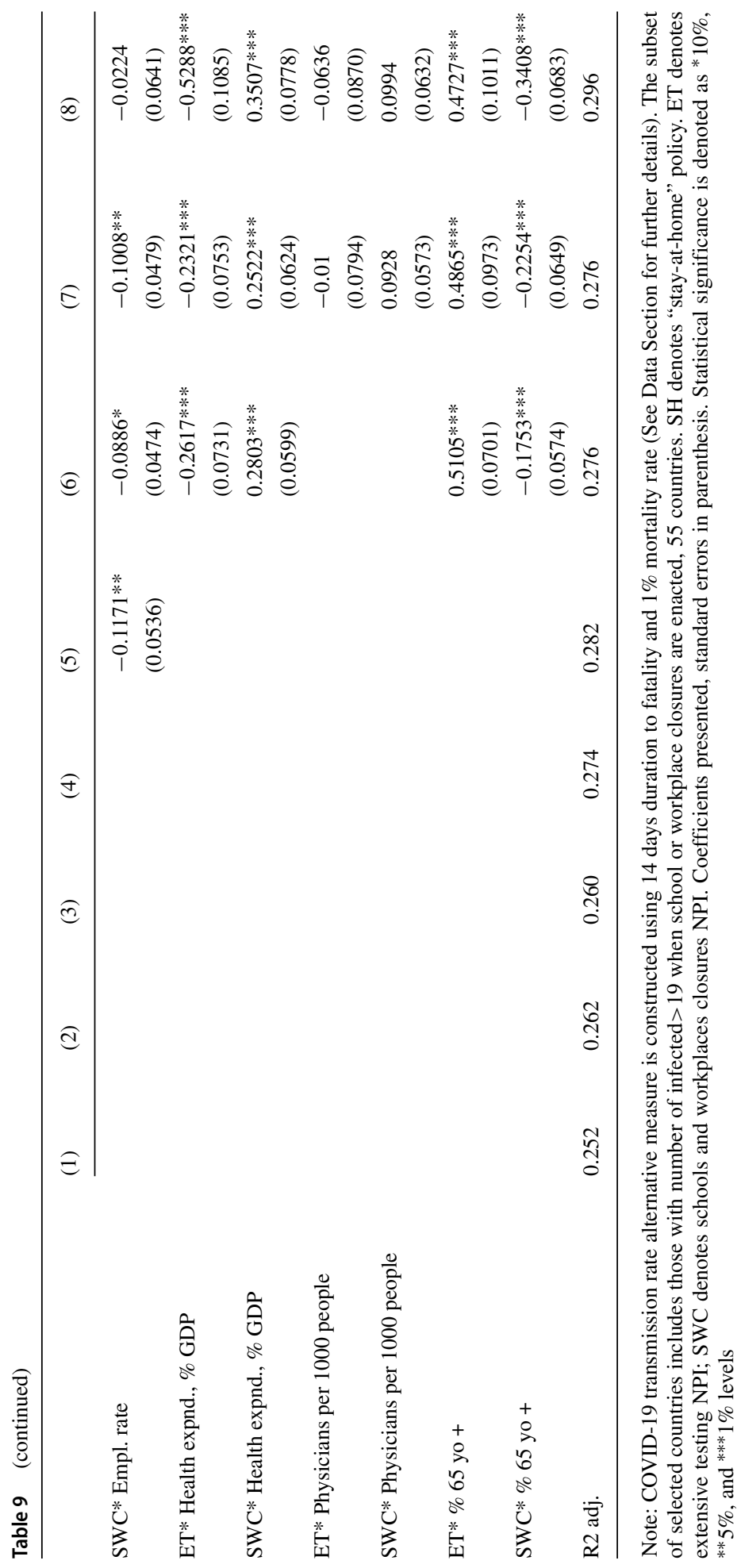


Table 10 Selected NPIs and change in daily Google mobility indexes, with country characteristics interactions, FE, selected countries, $\mathrm{N}=931$

\begin{tabular}{|c|c|c|c|c|c|}
\hline & $\begin{array}{l}\text { places of } \\
\text { residence }\end{array}$ & $\begin{array}{c}\text { shopping \& } \\
\text { restaurants }\end{array}$ & $\begin{array}{l}\text { transit } \\
\text { stations }\end{array}$ & $\begin{array}{l}\text { parks and } \\
\text { beaches }\end{array}$ & workplaces \\
\hline & (1) & (2) & (3) & (4) & $(5)$ \\
\hline $\mathrm{SH}\{0,1\}$ & $\begin{array}{l}4.7500 * * * \\
(0.7853)\end{array}$ & $\begin{array}{l}-18.5376 * * \\
(2.1970)\end{array}$ & $\begin{array}{c}*-17.6945 \text { *** } \\
(1.9856)\end{array}$ & $\begin{array}{c}*-14.8404 * * * \\
(3.0371)\end{array}$ & $\begin{array}{c}*-12.2028 * * * \\
(2.0726)\end{array}$ \\
\hline ET $\{0,1\}$ & $\begin{array}{l}3.4747 \\
(2.5306)\end{array}$ & $\begin{array}{l}-7.2428 \\
(7.0795)\end{array}$ & $\begin{array}{l}-6.9846 \\
(6.3983)\end{array}$ & $\begin{array}{l}-12.9569 \\
(9.7868)\end{array}$ & $\begin{array}{l}-6.9969 \\
(6.6789)\end{array}$ \\
\hline $\operatorname{SWC}\{0,1\}$ & $\begin{array}{l}8.5231 * * * \\
(0.4517)\end{array}$ & $\begin{array}{l}-22.6599 * * * \\
(1.2638)\end{array}$ & $\begin{array}{c}*-22.8909 * * * \\
(1.1422)\end{array}$ & $\begin{array}{c}*-8.3333 * * * \\
(1.7471)\end{array}$ & $\begin{array}{l}-19.2642 * * * \\
(1.1923)\end{array}$ \\
\hline $\mathrm{ET}\{0,1\} * \ln \mathrm{GDP}$ pc & $\begin{array}{l}-0.1754 \\
(1.3352)\end{array}$ & $\begin{array}{l}0.8619 \\
(3.7354)\end{array}$ & $\begin{array}{l}-2.5448 \\
(3.3760)\end{array}$ & $\begin{array}{l}-4.262 \\
(5.1639)\end{array}$ & $\begin{array}{l}0.793 \\
(3.5241)\end{array}$ \\
\hline $\operatorname{SWC}\{0,1\} * \ln$ GDP pc & $\begin{array}{l}1.7049 * * \\
(0.8394)\end{array}$ & $\begin{array}{l}-0.4116 \\
(2.3484)\end{array}$ & $\begin{array}{l}-4.4664 * * \\
(2.1224)\end{array}$ & $\begin{array}{l}6.7863 * * \\
(3.2464)\end{array}$ & $\begin{array}{l}-4.1433^{*} \\
(2.2155)\end{array}$ \\
\hline ET $\{0,1\} *$ Pop density & $\begin{array}{l}-5.7416 \\
(8.8919)\end{array}$ & $\begin{array}{l}27.5447 \\
(24.8756)\end{array}$ & $\begin{array}{l}24.1445 \\
(22.4822)\end{array}$ & $\begin{array}{l}-10.3581 \\
(34.3883)\end{array}$ & $\begin{array}{l}8.9891 \\
(23.4681)\end{array}$ \\
\hline SWC $\{0,1\} *$ Pop density & $\begin{array}{l}1.2112 \\
(1.2343)\end{array}$ & $\begin{array}{l}4.7433 \\
(3.4531)\end{array}$ & $\begin{array}{l}6.4500 * * \\
(3.1208)\end{array}$ & $\begin{array}{l}-5.5536 \\
(4.7736)\end{array}$ & $\begin{array}{l}-1.3419 \\
(3.2577)\end{array}$ \\
\hline ET $\{0,1\} * \ln$ surface area & $\begin{array}{l}-0.425 \\
(1.8496)\end{array}$ & $\begin{array}{l}-0.3478 \\
(5.1745)\end{array}$ & $\begin{array}{l}-0.0273 \\
(4.6766)\end{array}$ & $\begin{array}{l}-4.9618 \\
(7.1533)\end{array}$ & $\begin{array}{l}2.6434 \\
(4.8817)\end{array}$ \\
\hline SWC $\{0,1\} * \ln$ surface area & $\begin{array}{l}-2.2713^{* * *} \\
(0.6972)\end{array}$ & $\begin{array}{l}* 10.1710 * * * \\
(1.9506)\end{array}$ & $\begin{array}{l}5.8878 * * * \\
(1.7629)\end{array}$ & $\begin{array}{l}2.6459 \\
(2.6965)\end{array}$ & $\begin{array}{l}5.4783 * * * \\
(1.8402)\end{array}$ \\
\hline ET $\{0,1\} *$ PM 2.5 & $\begin{array}{l}0.9997 \\
(2.5832)\end{array}$ & $\begin{array}{l}-4.307 \\
(7.2266)\end{array}$ & $\begin{array}{l}0.7838 \\
(6.5313)\end{array}$ & $\begin{array}{l}3.4286 \\
(9.9901)\end{array}$ & $\begin{array}{l}0.7272 \\
(6.8177)\end{array}$ \\
\hline SWC $\{0,1\} *$ PM 2.5 & $\begin{array}{l}-3.6524 * * * \\
(0.4734)\end{array}$ & $\begin{array}{c}* 7.8357 * * * \\
(1.3243)\end{array}$ & $\begin{array}{l}7.5327 * * * \\
(1.1969)\end{array}$ & $\begin{array}{l}4.6032 * * \\
(1.8308)\end{array}$ & $\begin{array}{l}9.3784 * * * \\
(1.2494)\end{array}$ \\
\hline ET $\{0,1\} *$ Empl. rate & $\begin{array}{l}-4.4193 \\
(3.1182)\end{array}$ & $\begin{array}{l}6.9895 \\
(8.7234)\end{array}$ & $\begin{array}{l}4.1192 \\
(7.8840)\end{array}$ & $\begin{array}{l}11.1292 \\
(12.0593)\end{array}$ & $\begin{array}{l}8.7684 \\
(8.2298)\end{array}$ \\
\hline SWC $\{0,1\} *$ Empl. rate & $\begin{array}{l}-2.5362 \text { *** } \\
(0.6443)\end{array}$ & $\begin{array}{c}* 6.6738 * * * \\
(1.8024)\end{array}$ & $\begin{array}{l}6.1872 * * * \\
(1.6289)\end{array}$ & $\begin{array}{l}2.9846 \\
(2.4916)\end{array}$ & $\begin{array}{l}7.1370 * * * \\
(1.7004)\end{array}$ \\
\hline ET $\{0,1\} *$ Health expend. \%GDP & $\begin{array}{l}-0.9834 \\
(1.5591)\end{array}$ & $\begin{array}{l}2.5495 \\
(4.3616)\end{array}$ & $\begin{array}{l}5.6588 \\
(3.9419)\end{array}$ & $\begin{array}{l}-0.5059 \\
(6.0295)\end{array}$ & $\begin{array}{l}1.6302 \\
(4.1148)\end{array}$ \\
\hline SWC $\{0,1\} *$ Health expend. \%GDP & $\begin{array}{l}-1.6749 * * \\
(0.6850)\end{array}$ & $\begin{array}{l}3.5900 * \\
(1.9164)\end{array}$ & $\begin{array}{l}3.7627 * * \\
(1.7320)\end{array}$ & $\begin{array}{l}5.6748 * * \\
(2.6492)\end{array}$ & $\begin{array}{l}3.9480 * * \\
(1.8079)\end{array}$ \\
\hline ET $\{0,1\} *$ Physicians $/ 1000$ & $\begin{array}{l}2.9961 \\
(2.0387)\end{array}$ & $\begin{array}{l}-6.1762 \\
(5.7034)\end{array}$ & $\begin{array}{l}-4.9329 \\
(5.1546)\end{array}$ & $\begin{array}{l}-16.7703^{* *} \\
(7.8844)\end{array}$ & $\begin{array}{l}-5.8405 \\
(5.3807)\end{array}$ \\
\hline SWC $\{0,1\} *$ Physicians $/ 1000$ & $\begin{array}{l}0.1757 \\
(0.6137)\end{array}$ & $\begin{array}{l}-4.1994 * * \\
(1.7168)\end{array}$ & $\begin{array}{l}-2.2918 \\
(1.5516)\end{array}$ & $\begin{array}{l}-8.1691 * * * \\
(2.3733)\end{array}$ & $\begin{array}{l}-0.0946 \\
(1.6196)\end{array}$ \\
\hline ET $\{0,1\} * \% 65$ yo + & $\begin{array}{l}-0.5897 \\
(2.9061)\end{array}$ & $\begin{array}{l}0.3089 \\
(8.1300)\end{array}$ & $\begin{array}{l}3.2573 \\
(7.3478)\end{array}$ & $\begin{array}{l}20.4750 * \\
(11.2391)\end{array}$ & $\begin{array}{l}1.7687 \\
(7.6700)\end{array}$ \\
\hline
\end{tabular}


Table 10 (continued)

\begin{tabular}{llllll}
\hline & $\begin{array}{l}\text { places of } \\
\text { residence }\end{array}$ & $\begin{array}{c}\text { shopping \& } \\
\text { restaurants }\end{array}$ & $\begin{array}{c}\text { transit } \\
\text { stations }\end{array}$ & $\begin{array}{l}\text { parks and } \\
\text { beaches }\end{array}$ & workplaces \\
\cline { 2 - 6 } & $(1)$ & $(2)$ & $(3)$ & $(4)$ & $(5)$ \\
SWC $\{0,1\} * \% 65$ yo + & $-2.7104 * * *$ & $5.2031 * * *$ & $4.7482 * * *$ & $6.8678 * *$ & $5.8205 * * *$ \\
R2 adj. & $(0.6909)$ & $(1.9330)$ & $(1.7470)$ & $(2.6721)$ & $(1.8236)$ \\
\hline
\end{tabular}

Note: The subset of selected countries Google mobility data shows how time spent in different location categories changed compared to the baseline days (a normal value for that day of the week in the 5-week period Jan 3 - Feb 6, 2020). ET denotes extensive testing NPI; SWC denotes schools and/or workplaces closures; SH denotes "stay-at-home" NPI. Coefficients presented, standard errors in parenthesis. Statistical significance is denoted as $* 10 \%, * * 5 \%$, and $* * * 1 \%$ levels

\section{References}

Acemoglu D, Makhdoumi A, Malekian A, Ozdaglar A (2020) Testing, Voluntary social distancing and the spread of an infection. Technical Report, National Bureau of Economic Research

Adda J (2016) Economic activity and the spread of viral diseases: Evidence from high frequency data. Q J Econ:891-941

Ahmed F, Ahmed N, Pissarides C, Stiglitz J (2020) Why inequality could spread Covid-19, The Lancet Public Health

Andersen AL, Hansen ET, Johannesen N, Sheridan A (2020) Pandemic, shutdown and consumer spending: Lessons from scandinavian policy responses to COVID-19. Proceedings of the National Academy of Sciences, pp 202010068. https://doi.org/10.1073/pnas.2010068117

Atkeson AG (2020) What will be the economic impact of COVID-19 in the US? Rough estimates of disease scenarios. Staff Report 595, Federal Reserve bank of Minneapolis

Askitas N., Konstantinos T, Verheyden B (2020) Lockdown strategies, mobility patterns and covid-19. IZA Discussion Paper No. 13293

Barmby T, Larguem M (2009) Coughs and sneezes spread diseases: an empirical study of absenteeism and infectious illness. J Health Econ 28:1012-1017

Borjas GJ (2020) Demographic determinants of testing incidence and covid-19 infections in new york city neighbourhoods. Covid Economics: Vetted and Real-Time Papers 3:12-39

Brzezinski AG, Deiana VK, Van Dijcke D (2020) The COVID-19 pandemic: Government versus community action across the United States, Covid Economics: Vetted and Real-Time Papers, Issue 7

Centers for Disease Control and Prevention COVID-19 Response Team (2020) Morbidity and mortality weekly report: Preliminary Estimates of the Prevalence of Selected Underlying Health Conditions Among Patients with Coronavirus Disease 2019, United States, February 12 - March 28, 2020, Available at: https://www.cdc.gov/mmwr/volumes/69/wr/mm6913e2.htm

Chen X, Qiu Z (2020) Scenario analysis of non-pharmaceutical interventions on global Covid-19 transmissions Covid Economics: Vetted and Real-Time Papers, Issue 7

Conticini E, Frediani B, Caro D (2020) Can atmospheric pollution be considered a co-factor in extremely high level of SARS-cov-2 lethality in Northern Italy? Environ Pollut 261:114465

Cho S (2020) Quantifying the Impact of Non-pharmaceutical Interventions (NPI) during the COVID-19 Outbreak - The Case of Sweden, COVID Economics: Vetted and Real-time Papers, Issue 35

Fang H, Wang L, Yang Y (2020) Human Mobility Restrictions and the Spread of the Novel Coronavirus (2019-nCoV) in China. NBER Working Paper No. 26906

Fernandez-Villaverde J, Jones C (2020) Estimating and simulating a SIRD model of COVID-19 for many countries, states, and cities. NBER Working Paper No. 27128

Friedson A, McNicols D, Sabia J, Dhaval D (2020) Did california's shelter in place order work? early Coronavirus-Related public health effects. IZA DP No. 13160

Glaeser EL, Gorback CS, Redding SJ (2020) How Much does Covid-19 Increase with Mobility? Evidence from New York and Four Other U.S. Cities, NBER Working Paper No. 27519

Hale T, Angrist N, Kira B, Petherick A, Phillips T, Webster S (2020) Variation in government responses to COVID-19: version 5.0, Blavatnik School of Government, University of Oxford. BSG 
Working Paper Series; 2020/032. Available from: https://www.bsg.ox.ac.uk/sites/default/files/2020-05/ BSG-WP-2020-032-v5.0_0.pdf

Hartl T, Walde K, Weber E (2020) Measuring the impact of the German public shutdown on the spread of COVID19, Covid economics, Vetted and real-time papers. CEPR press 1:25-32

Jinjarak Y, Ahmed R, Nair-Desai S, Xin W, Aizenman J (2020) Accounting for global COVID-19 diffusion patterns, January-April 2020. NBER Working Paper No. 27185

Kucharski A. J., Russell TW, Diamond C, Liu Y, Edmunds J, Funk S, Eggo RM, Sun F, Jit M, Munday JD et al (2020) Early dynamics of transmission and control of COVID-19: a mathematical modelling study, The Lancet Infectious Diseases

Lauer SA, Grantz KH, Bi Q, Jones FK, Zheng Q, Meredith HR, Azman AS, Reich NG, Lessler J (2020) The Incubation Period of Coronavirus Disease 2019 (COVID-19) From Publicly Reported Confirmed Cases: Estimation and Application. Annals of Internal Medicine. https://doi.org/10.7326/M20-0504

Li Q, Guan X, Wu P, Wang X, Zhou L, Tong Y, Ren R, Leung K, Lau EH, Wong JY et al (2020) Early transmission dynamics in Wuhan, China, of novel coronavirus-infected pneumonia. New England Journal of Medicine

Linton NM, Kobayashi T, Yang Y, Hayashi K, Akhmetzhanov AR, Jung S-M, Yuan B, Kinoshita R, Nishiura $H$ (2020) Incubation period and other epidemiological characteristics of 2019 novel Coronavirus infections with right truncation: A statistical analysis of publicly available case data. J Clin Med 9(2). www. mdpi.com/2077-0383/9/2/538

Lloyd-Smith JO, Schreiber SJ, Kopp PE, Getz WM (2005) Superspreading and the effect of individual variation on disease emergence. Nature 438(7066):355-359

Markowitz S, Nesson E, Robinson J (2019) The effects of employment on influenza rates. Econ Hum Biol 34:286-295

Pichler S, Ziebarth NR (2017) The pros and cons of sick pay schemes: Testing for contagious presenteeism and noncontagious absenteeism behavior. J Public Econ 156:14-33

Setti L, Passarini F, De Gennaro G, Barbieri P, Perrone MG, Borelli M et al (2020) Airborne transmission Route of COVID-19: Why 2 Meters/ 6 Feet of Inter-Personal Distance Could Not Be Enough. Int J Enviro Res Publ Health 17(8):2932

Verity R, Okell LC, Dorigatti I, Winskill P, Whittaker C, Imai N, Cuomo-Dannenburg G, Thompson H, Walker PGT, Fu H, Dighe A, Griffin JT, Baguelin M, Bhatia S, Bonyasiri A, Cori A, Cucunuba Z, FitzJohn R, Gaythorpe K, Green W, Hamlet A, Hinsley W, Laydon D, Nedjati-Gilani G, Riley S, van Elsland S, Volz E, Wang H, Wang Y, Xi X, Donnelly CA, Ghani AC, Ferguson NM (2020) Estimates of the severity of coronavirus disease a Model-Based analysis, the lancet: Infectious diseases 2019: A Model-Based Analysis, The Lancet: Infectious Diseases

Wu JT, Leung K, Leung GM (2020a) Nowcasting and forecasting the potential domestic and international spread of the 2019-nCoV outbreak originating in Wuhan, China: a modelling study. Lancet 395(10225):689-697

Wu Z, McGoogan JM (2020b) Characteristics of and Important Lessons From the Coronavirus Disease 2019 (COVID-19) Outbreak in China: Summary of a Report of 72,314 Cases From the Chinese Centers for disease Control and Prevention, JAMA

Zachreson C, Fair K, Cliff OM, Harding M, Piraveenan M, Prokopenko M (2018) Urbanization affects peak timing, prevalence, and bimodality of influenza pandemics in Australia: results of a census-calibrated model. Science Advances:4

Ullah A, Ajala OA (2020) Do lockdown and testing help in curbing Covid-19 transmission?, Covid Econ $13: 138156$

Publisher's Note Springer Nature remains neutral with regard to jurisdictional claims in published maps and institutional affiliations. 